\title{
II Disegno e la Scuola Superiore di Architettura
}

\author{
Laura Carnevali \\ Marco Fasolo \\ Fabio Lanfranchi
}

Abstract

Nel 1919 viene istituita la Scuola Superiore di Architettura romana - inaugurata nel 1920 - dalla quale viene finalmente a delinearsi un preciso profilo professionale, quello dell'architetto. L'acceso dibattito internazionale caratterizzante il pluralismo di opinioni del XIX Secolo tra i sostenitori del disegno accademico legato all'Ecole des Beaux-Arts e coloro che difendono i fondamenti del disegno geometrico in nome dell'istruzione tecnica diffusa dall'Ecole Politechnique, trova quindi, almeno in Italia, un riferimento utile alla ridefinizione di una figura il cui preciso ruolo si era iniziato a perdere con l'avvento del XVIII secolo. È dagli scritti di Gustavo Giovannoni, massima autorità della cultura architettonica ufficiale di quel periodo, che si possono evincere le caratteristiche della 'nuova figura professionale' che la neo Scuola di Architettura di Roma si poneva l'obiettivo di formare: 'l'architetto integrale'. Tale figura, come enunciato da Giovannoni e pienamente condiviso dagli altri Maestri del mondo dell'architettura del periodo, doveva possedere un bagaglio culturale completo nell'ambito artistico, scientifico e storico, per quanto attiene l'ambito dell'arte e dell'architettura, oltre ad una specifica competenza inerente la costruzione e l'amministrazione. II presente contributo intende fornire un'anteprima della ricerca, ancora in atto, circa l'insegnamento del Disegno nei primi decenni dall'inaugurazione della Scuola Superiore di Architettura di Roma.

Parole chiave

Scuola Superiore di Architettura, Roma, Disegno.

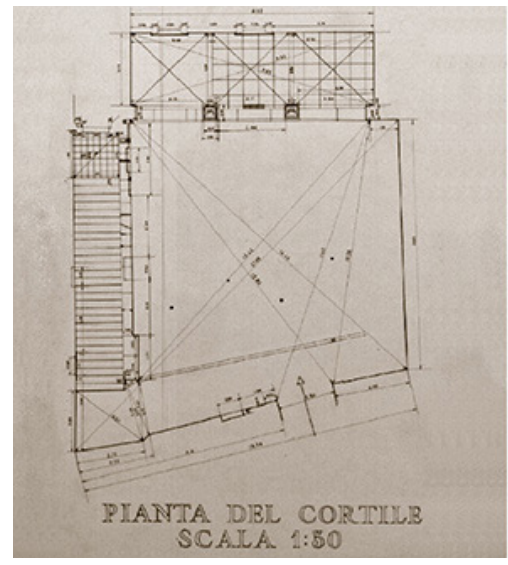

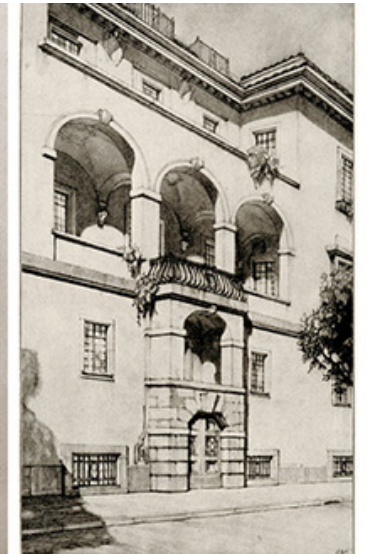

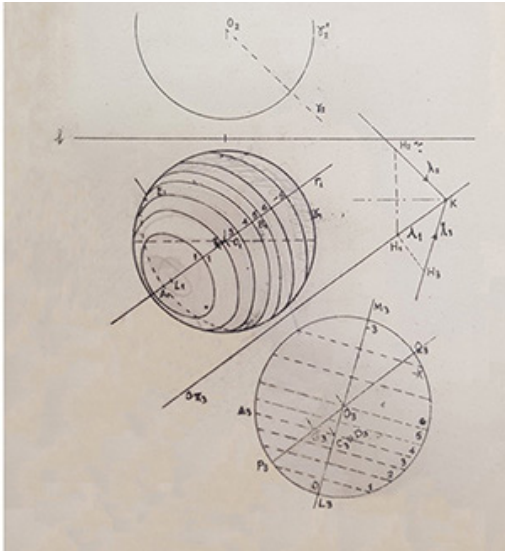

doi.org/ | 0.3280/oa-548. I5 


\section{Antefatti e clima culturale: la (Ri)nascenza dell'architetto integrale}

Nei primi anni del $X X$ secolo negli ambienti artistici la tradizione ottocentesca e l'insegnamento accademico si spingono verso una nuova cultura della modernità e, dalla fine degli anni Dieci, tutte le arti figurative risentono del nuovo fermento culturale influenzato, in gran parte, dall'arte Europea. Ma l'architettura e la cultura progettuale italiana sembrano resistere alle tendenze culturali d'oltralpe. Come afferma Marcello Piacentini in un articolo del 1921 pubblicato su Architettura ed Arti Decorative: "Siamo ancora [...] nel grasso borghesismo architettonico, che ostenta una ricchezza inesistente [...]. Noi facciamo ancora un'architettura da capomastri presuntuosi"' [Piacentini 1921, p. 75]. Sempre Piacentini, definisce il Disegno dell'architettura di questo periodo "sotto la cappa dello stilismo stereotipo" [Piacentini 1921, p. 75]. Grazie all'opera di giovani architetti, alla fine degli anniVenti, si assiste ad una semplificazione del linguaggio grafico che esprime una nuova architettura capace di confrontarsi con le nuove tendenze europee. In questo clima maturano ferventi trasformazioni e per quanto riguarda l'architettura si fa sempre più pressante l'esigenza di formare una nuova figura professionale i cui insegnamenti provenissero da un organismo diverso dai due istituti preposti alla sua formazione, ossia dalle Accademie di Belle Arti, dove lo studio artistico era carente di contenuto tecnico ed in parte anche culturale e, al contempo, dalle Scuole di Ingegneria dove l'architettura era considerata uno dei rami delle costruzioni, quindi lontani da una concezione unitaria dalla quale poteva nascere la capacità di sintesi per la realizzazione di edifici utili, saldi ed espressione di un pensiero armonico. Da circa trent'anni il dibattito sull'insegnamento architettonico in Italia era fervido ma le appassionate discussioni sull'argomento non erano riuscite a produrre alcun risultato pratico. L'accorpamento delle due forme di insegnamento in una unica Scuola fu tentato per la prima volta nel 19/4 da Giovanni Rosadi [I], ma fu un fallimento anche se riuscì a sensibilizzare l'opinione pubblica sul problema. Ė nel 1919 che venne istituita la Scuola Superiore di Architettura (la prima in Italia), inaugurata 1920 e dalla quale si delineò il profilo del nuovo professionista. Ė dagli scritti di Gustavo Giovannoni, massima autorità della cultura architettonica ufficiale di quel periodo (professore di architettura presso la Reale Scuola di Ingegneria di Roma, Direttore della Scuola Superiore di Architettura di Roma e docente di Restauro dei monumenti)

Fig. I. Corso di Elementi di Architettura e Rilievo dei Monumenti, 193839. Studente Agesilao Anastasi, Palazzo Taverna, coll. ARDIS 29I (Archivio Disegni del Dipartimento di Storia, Disegno e

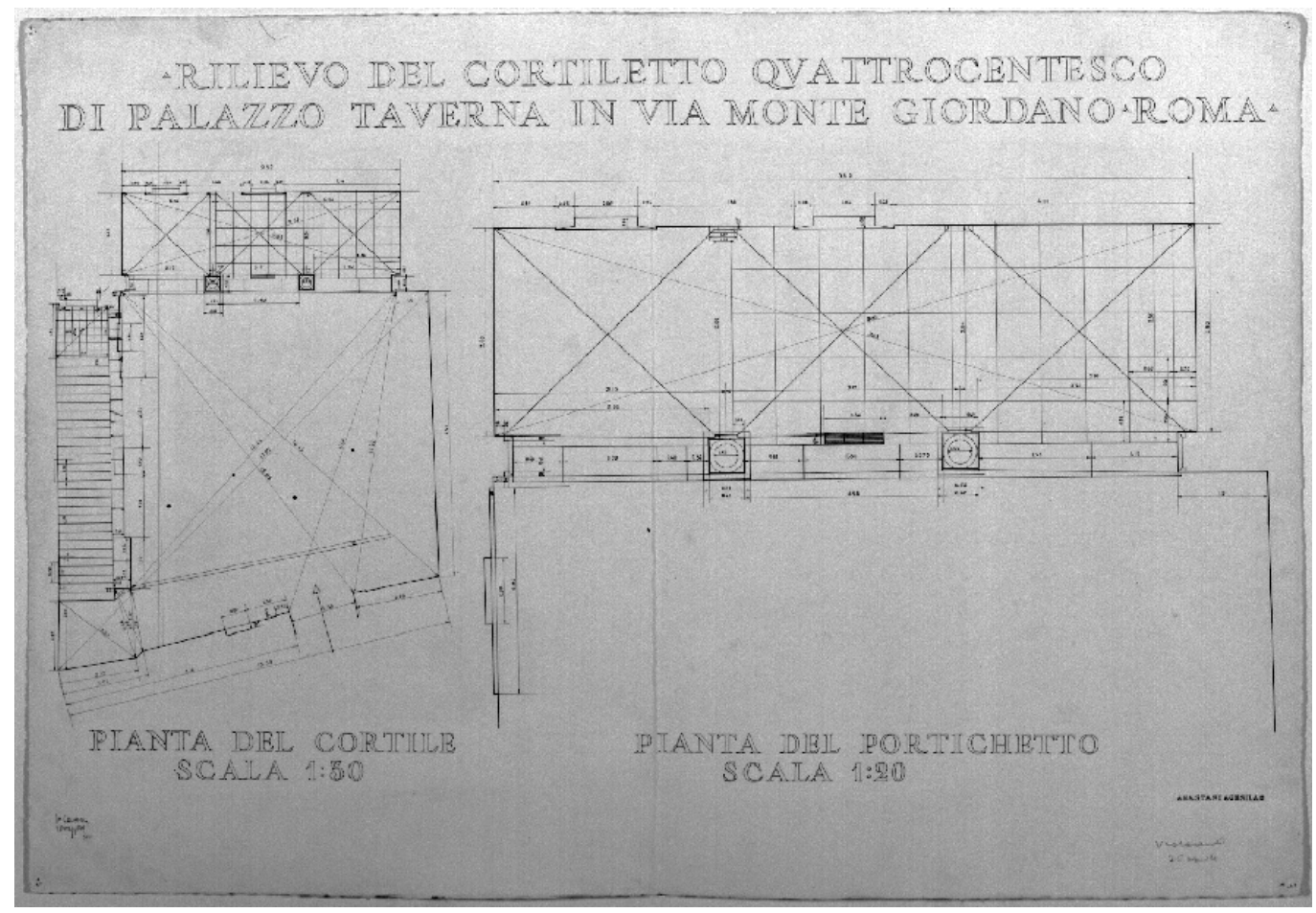


che si possono evincere le caratteristiche della figura professionale che la nuova Scuola di Architettura di Roma si poneva l'obiettivo di formare: "l'architetto integrale" [2]. Tale figura, come enunciato da Giovannoni, ma condivisa dagli altri Maestri del mondo dell'architettura, doveva possedere un bagaglio culturale completo, una solida preparazione artistica, un'adeguata preparazione scientifica, una conoscenza della storia dell'arte e dell'architettura, ed una esperienza relativa ai problemi legati alla costruzione e all'amministrazione. In questo nuovo contesto il Disegno divenne centrale e fu caratterizzato da numerose esercitazioni attraverso bozzetti, da taccuini dai soggetti più disparati, da esercitazioni di rilievo (figg. I, 2) e ancora da disegni dal vero (figg. 3,4 ) e da fotografie. Sebbene nella formazione si è ancora lontani da un insegnamento tout court del disegno, esso è mezzo e strumento transdisciplinare idoneo a rivestire un ruolo assolutamente determinante in tutte le discipline in cui viene praticato nell'ambito della Scuola. Dell'alto valore formativo e comunicativo del disegno erano fortemente convinti quegli "architetti" che riuniti da Giovannoni nel 1920 presso gli angusti locali dell'Accademia di Belle Arti in via di Ripetta, sede provvisoria della Scuola, discutevano, anche animatamente, sull'indirizzo culturale che la nuova istituzione doveva assumere. Di questo gruppo facevano parte Manfredo Manfredi, Giulio Magni, Giovan Battista Milani, Fausto Vagnetti, Marcello Piacentini, Arnaldo Foschini, Vincenzo Fasolo, P. Santini [3] molti dei quali membri dell'Associazione Artistica tra i cultori di architettura e che ricoprirono fin dal primo anno accademico, 1920-1921, il ruolo di docenti negli insegnamenti a loro più pertinenti secondo le loro indiscusse competenze.

\section{Dal Ferro di Cavallo alla Regia Scuola Superiore di Architettura, un percorso condotto attraverso un chiaro Disegno}

II 1932 segna un'importante data per la Scuola, infatti in quell'anno viene inaugurata la nuova sede di Valle Giulia su progetto di Del Debbio, tre anni dopo la Scuola lascerà il posto alla Facoltà di Architettura (fig. 5). Gli insegnamenti previsti nell'a.a. 1931-1932 e suddivisi in quattro cicli didattici: scientifico-tecnico; artistico; storico-artistico; architettonico, erano concepiti per formare quella figura professionale in grado di connettere gli studi artistici

Fig. 2. Corso di Elementi di Architettura e Rilievo dei Monumenti II, Facoltà di Architettura. Studente R. Colella, anni 50 (Archivio Disegni del Dipartimento di Storia, Disegno e Restauro

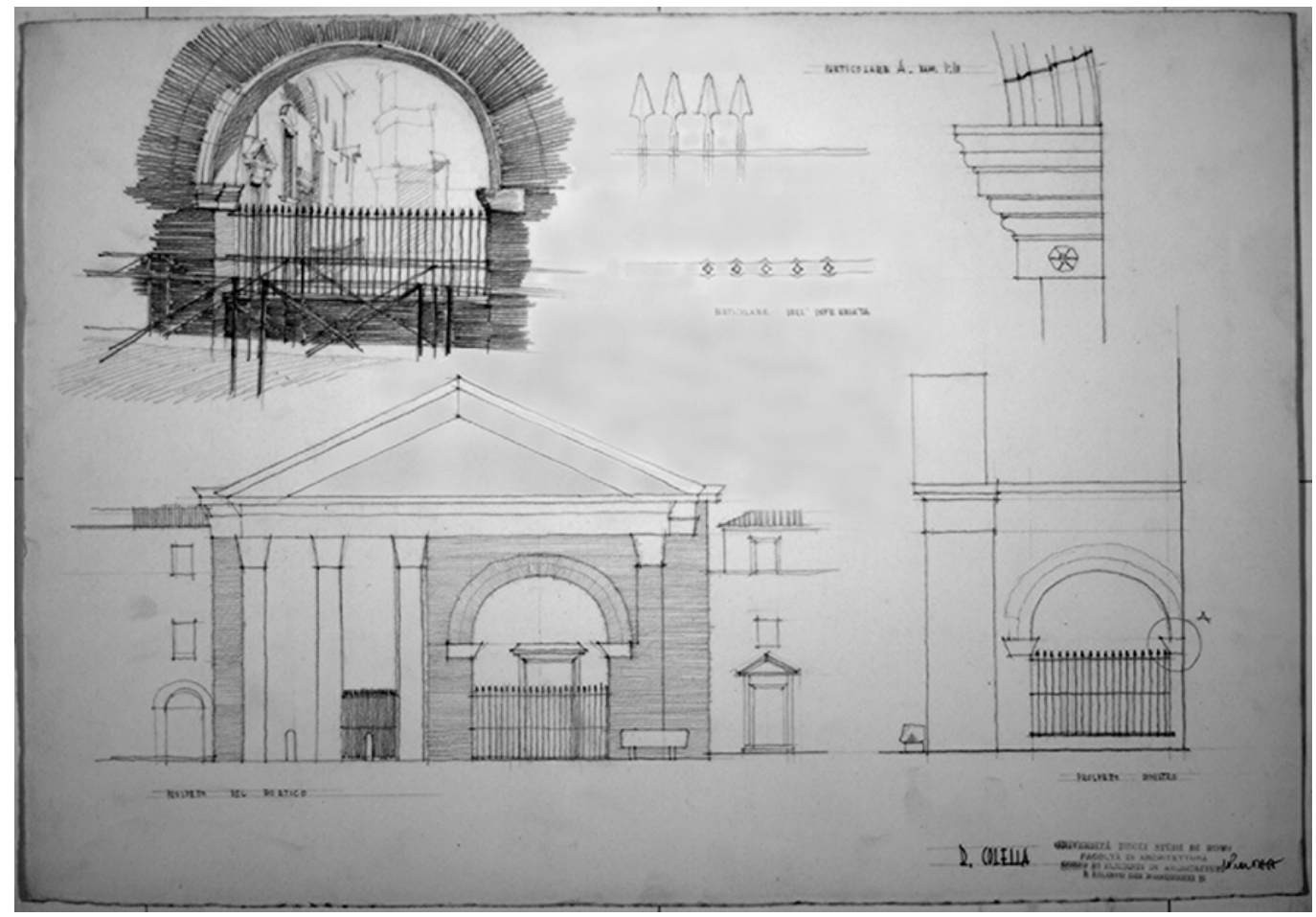


con quelli scientifici sinteticamente definita come architetto integrale. I docenti chiamati a insegnare queste materie vennero individuati tra coloro che per manifesta capacità culturale avrebbero dato lustro agli insegnamenti loro affidati. Ricordiamo tra tutti Ugo Amaldi per Analisi matematica, Enrico Bompiani per Geometria descrittiva (fig. 6), Vincenzo Fasolo per Storia e Stili dell'Architettura, Giuseppe Boni per Elementi costruttivi, Luigi Vagnetti per Disegno d'ornato e figura, Enrico Del Debbio per Disegno architettonico ed elementi di composizione, Francesco Severi per Applicazioni di geometria descrittiva (fig. 7), Gustavo Tognetti per Rilievo dei monumenti, Giulio Ferrari per Decorazione pittorica, Giovanni Prini per Plastica ornamentale, Arnaldo Foschini per Composizione architettonica, Vittorio Morpurgo per Arredamento e Decorazione interna, Giovanni Battista Milani per Tecnica delle costruzioni, Giovanni Cicconetti per Topografia e costruzioni stradali, Marcello Piacentini per Edilizia e Arte dei giardini, Gustavo Giovannoni per Restauro dei monumenti,Vittorio Grassi per Scenografia. Leggendo questi nomi riconosciamo in essi molti dei grandi Maestri che hanno caratterizzato con il loro operato l'architettura di quel periodo. Nei grafici dei loro progetti è difficile discernere gli aspetti compositivi da quelli rappresentativi, la poetica dalla prosa. Luigi Moretti nel 1936 su Quadrivio afferma: "il concepirsi graficamente è il modo naturale dell'esprimersi dell'architettura contemporanea. Oggi la costruzione è una pura e semplice proiezione del grafico, e non, come dovrebbe essere e come è sempre stato, il grafico una proiezione della costruzione" [Diemoz 1936, p. 5]. II disegno dunque si configura magistralmente in quel periodo come mezzo non solo espressivo ma anche di riflessione interiore per comprendere sia l'architettura già costruita che per sperimentare, verificare e comunicare le proprie idee progettuali. E se è vero, come è vero, che questa concezione del disegno era fortemente radicata nel pensiero dei docenti del tempo - tutti valenti progettisti - non ci dobbiamo stupire se la 'pratica' del disegno fosse ben presente in tutti gli insegnamenti che dovevano formare quell'architetto integrale caro a Giovannoni. Pertanto il disegno assunse quel ruolo di imprescindibile medium culturale attraverso il quale i concetti impartiti durante le lezioni vedevano concretizzare, grazie ad esso, il loro insegnamento. Basta scorrere i testi dei programmi degli insegnamenti presenti negli ordinamenti di quegli anni e di quelli a seguire per ritrovare, tra i vari argomenti esclusivi di ciascuna materia, espliciti riferimenti al disegno testimoniati anche dalle pregevoli tavole grafiche prodotte dagli studenti a corredo

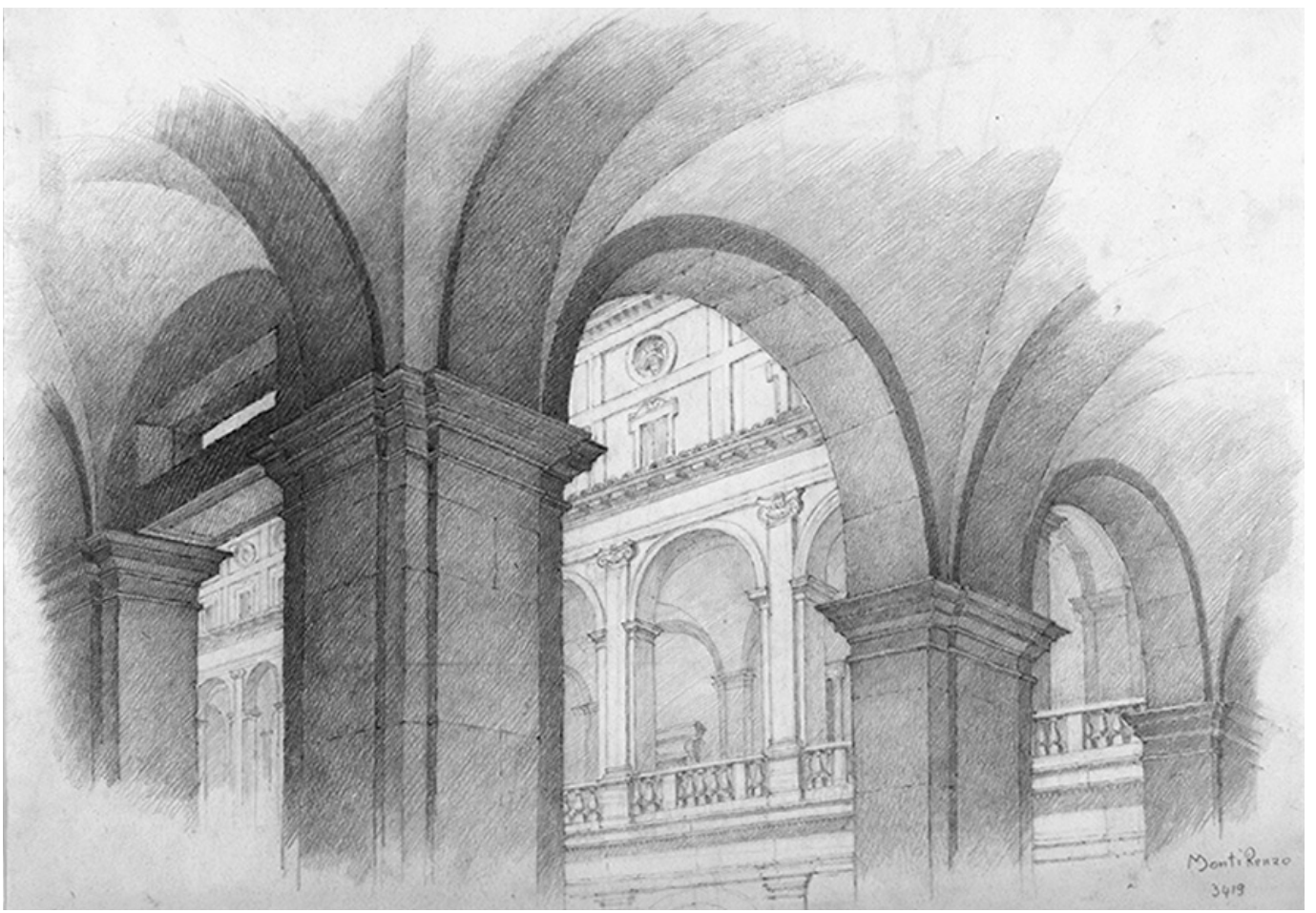




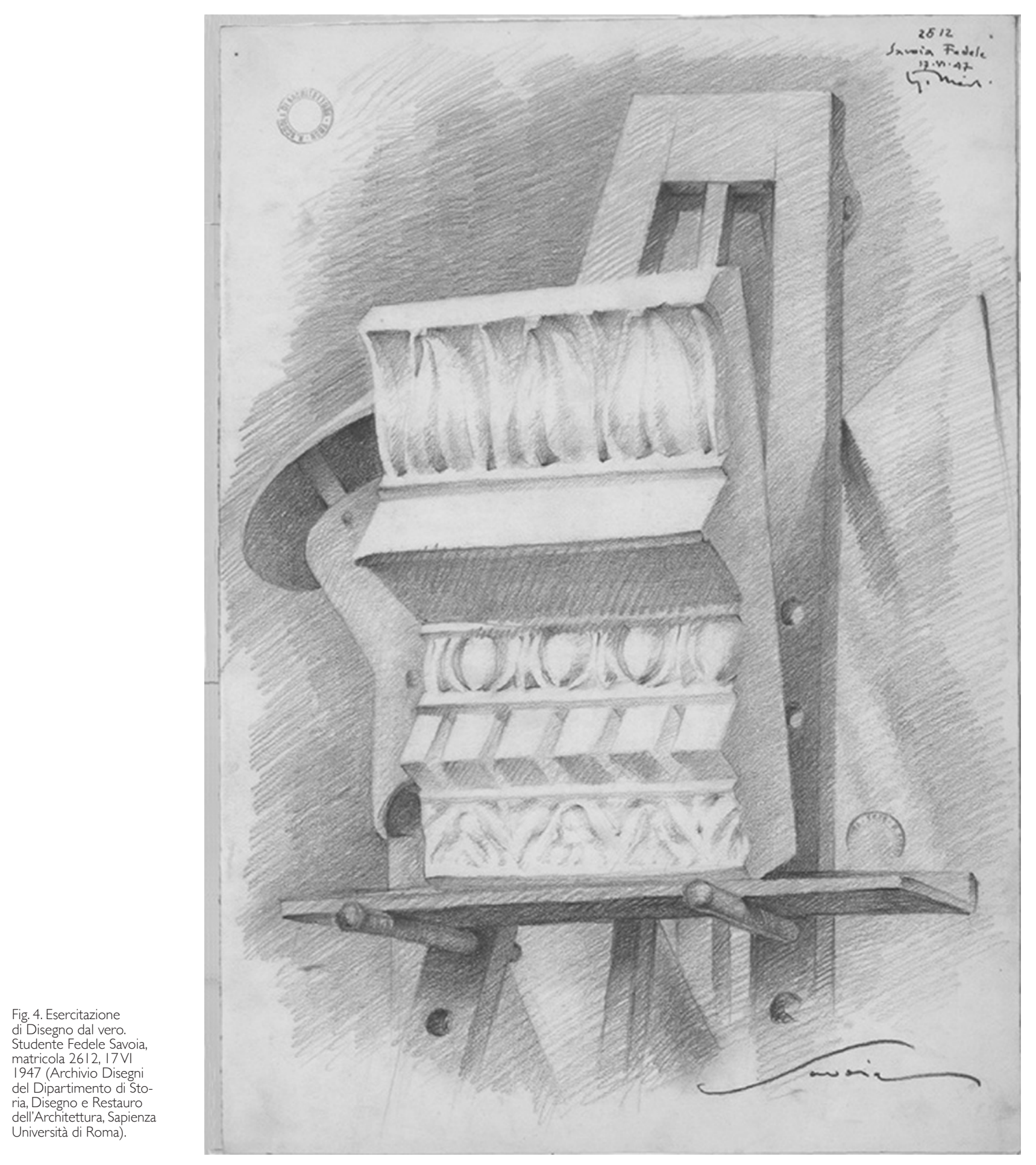


degli obiettivi formativi dei singoli corsi. Per necessaria sinteticità riportiamo alcune citazioni presenti nell'annuario del 1954-1955 relative alla componente artistica propria del disegno presente in alcuni corsi: "Elementi di Architettura e Rilievo dei Monumenti e di Disegno dal vero, ambedue corsi biennali; nel primo l'allievo, attraverso il rilevamento di edifici esistenti, inizia la consuetudine di mettere in corrispondenza il disegno con gli oggetti e acquista il senso della 'misura' delle cose, [...] comincia ad acquistare la capacità di tradurre in linee un proprio pensiero; nel secondo l'allievo si addestra alla rappresentazione rapida di oggetti in prospettiva ombreggiata, nel loro naturale ambiente, e ciò facendo si rende consapevole della particolare importanza che il gioco della luce e dell'atmosfera e delle loro variazioni ha sul risultato estetico finale di una architettura" [Vagnetti, Dall'Osteria 1955, p. I4]. Questi insegnamenti sono affiancati da quelli della Geometria descrittiva con Elementi di proiettiva e dalle sue Applicazioni "che danno un substrato teorico e quindi un più preciso strumento pratico, alla corretta rappresentazione di quanto l'occhio vede o la fantasia suggerisce" [ $\mathrm{Va}$ gnetti, Dall'Osteria 1955, p.I 4]. Accanto a queste materie c'é il corso di Plastica che "abitua i giovani a controllare il rapporto tra le forme pensate e il loro effetto reale" [Vagnetti, Dall'Osteria 1955, p.I4]. II primato del disegno nella sua valenza di mezzo conoscitivo e comunicativo veniva ampiamente riconosciuto e praticato nella quasi totalità dei corsi e sull'importanza di educare gli allievi a padroneggiare questo strumento citiamo lo stesso Giovannoni quando ricordava il monito di Luigi Cremona [4]:"a nessuna persona culta dovrebbe essere permesso di ignorare il disegno" [5]. L'impostazione didattica di Giovannoni, o in altre parole la concezione del disegno di quella Scuola, a nostro giudizio, iniziò ad incrinarsi, fino a dissolversi, in tre distinti momenti storici del XX secolo: gli anni Sessanta con il movimento studentesco, gli anni Ottanta con la riforma universitaria, gli anni Novanta con la ormai diffusa rivoluzione informatica.

\section{Considerazioni critiche}

Ciò premesso, considerando il sia pur sintetico quadro generale sullo stato dell'arte in materia, lo sviluppo della ricerca, inquadrandosi nell'ambito generale della Scuola di Architettura di Roma, si sta orientando sulle specificità proprie dell'ambito didattico relativo all'area del Disegno. Più in particolare l'intento è quello di 'penetrare' tra le maglie della didattica eroga-

Fig. 5. Gruppo di docenti sulla scalinata della nuova sede della Facoltà di Architettura a Valle Giulia in occasione della sua inaugurazione il 23 novembre 1932. Si riconoscono:Vincenzo Fasolo in basso a sinistra, Gustavo Giovannoni al centro in alto, Enrico Del Debbio alla destra di Giovannoni, Marcello Piacentini a destra, terzo dal basso [Crevato-Selvaggi 201।. p. 56].

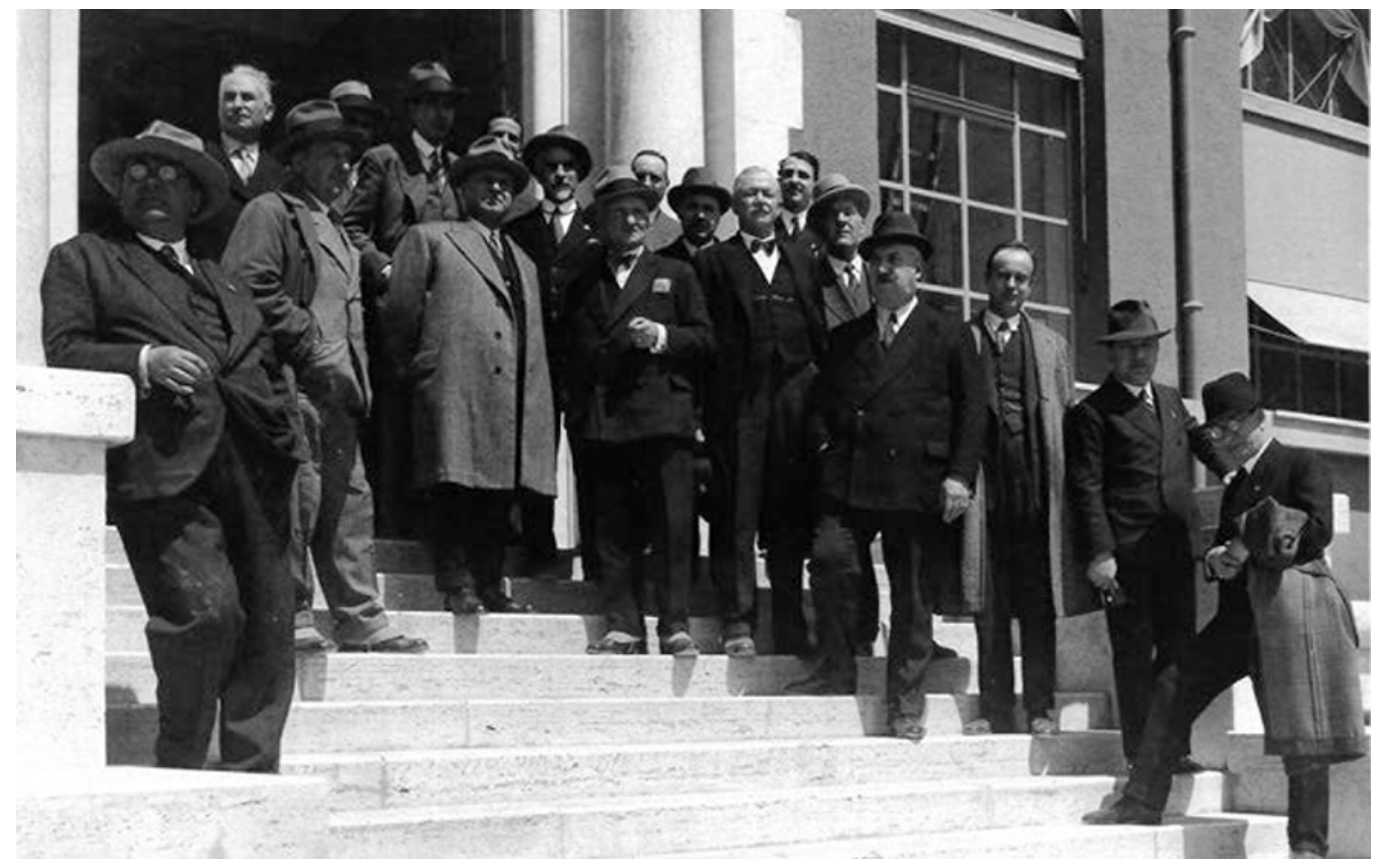


ta dai Maestri fondatori dall'istituzione della Scuola fino al virtuale momento del passaggio alla generazione successiva. La valenza scientifica di tale disamina riteniamo possa assumere un particolare rilievo anche considerando, come precedentemente accennato, che non è possibile inquadrare, in quello specifico contesto, il Disegno con quell'attuale autonomia disciplinare che verrà normata solo molti anni dopo la fondazione della Scuola. Una Scuola allora fermamente improntata sul disegnare ancora inteso come comune denominatore per lo svolgimento di quell'articolata attività artistica e professionale connotante il fare Architet-

Fig. 6. Enrico Bompiani, 1928, Iperboloide ad una falda [Bompiani 1928, pag. 187, fig. 9].

Fig. 7. Francesco Severi, 1936, Isofote della sfera [Severi 1936, p. 223]
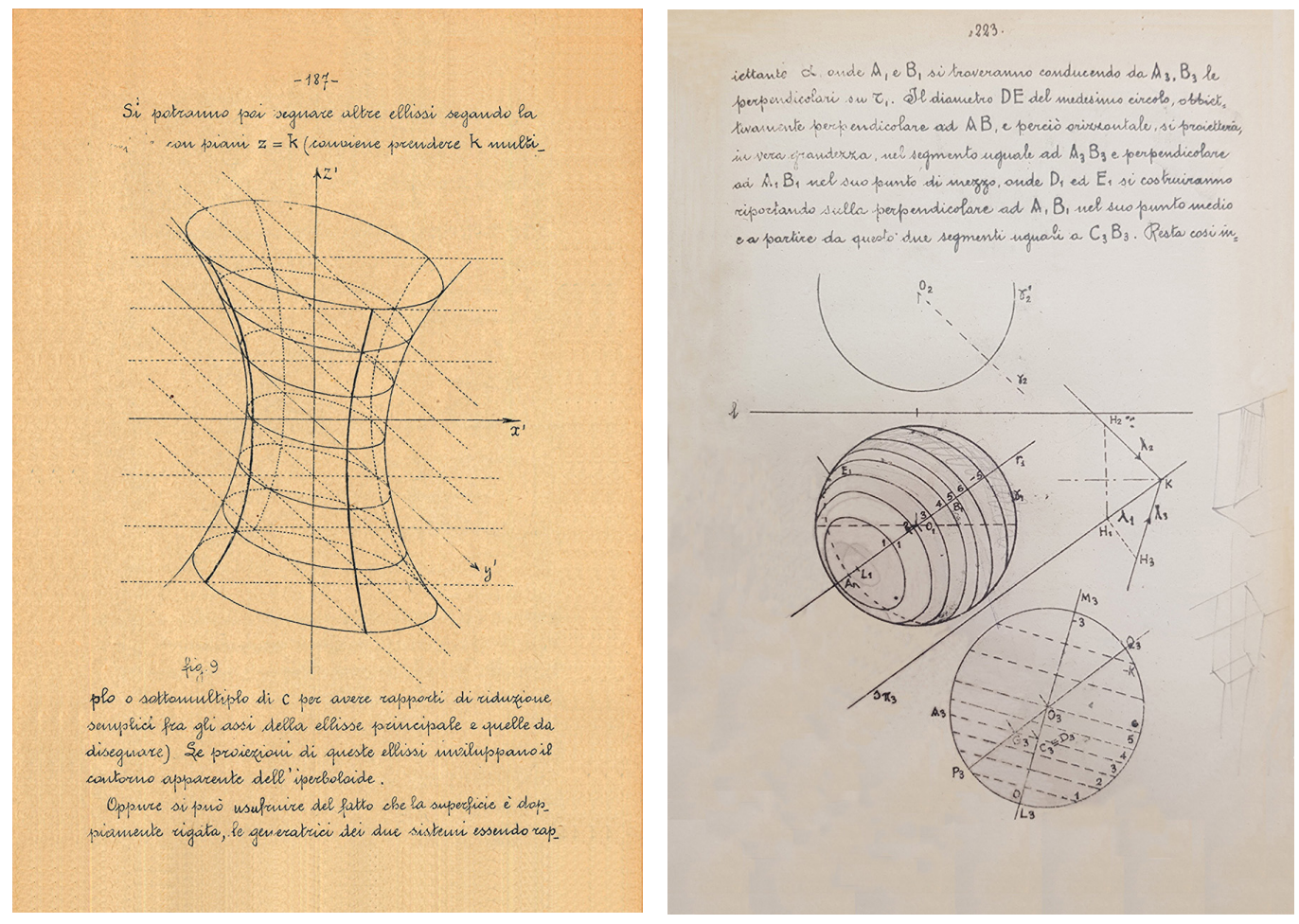

tura. Una 'trasversalità', quella del Disegno, che è opportuno notare, non generava equivoci dal punto di vista operativo, il mezzo grafico infatti veniva usato con assoluta proprietà e pertinenza a seconda dell'impiego; in definitiva nessuna distinzione tra Disegno inteso come specifica attività espressiva, Disegno come strumento culturale di conoscenza e Disegno in funzione d'un processo architettonico. II Disegno artistico ed il Disegno tecnico convergono nella neonata Scuola con i relativi 'linguaggi' ma di fatto senza la necessità di individuare in particolari materie e docenti il compito di trasmettere le relative regole 'linguistiche'. Appaiono lontani i padri fondatori della Scuola Superiore di Architettura di Roma dalle complesse elaborazioni della seconda metà degli anni Sessanta relativi ai modelli della linguistica applicata all'architettura o meglio della semiologia, ossia dalle tesi di Koenig, Eco o di De Fusco, così come tanti altri studiosi, atti a svelare i processi della significazione dell'architettura, accettando del modello verbale ciò che si poteva applicare al segno architettonico e scontrandosi con la difficoltà a riconoscere l'elemento significante, alle scale di fonema e di parola, ed il suo significato. Tesi a ripensarci forse anticipatorie di quel processo di suddivisione in definiti e rigorosi comparti specialistici che vedranno la luce nei primi anni Ottanta. Riteniamo che nella dottrina diffusa dai fondatori della Scuola di Architettura il linguaggio era ben presente ma esente dai fardelli della meccanica dello strutturalismo e senza la sua rigidità terminologica e la conseguente dichiarazione di adesione ad una scuola o ad un autore. Nei numerosi esempi grafici degli studenti licenziati in quel periodo (figg. 8- I I), affiora la tradizione culturale romana nel campo dell'analisi grafica che, da Vincenzo Fasolo in poi, 
Fig. 8. Un disegno della tesi di Luigi Piccinato tra i primi laureati alla Scuola di Architettura [Architettura e Arti Decorative MCMXXIV-MCMXXV, p. 109].

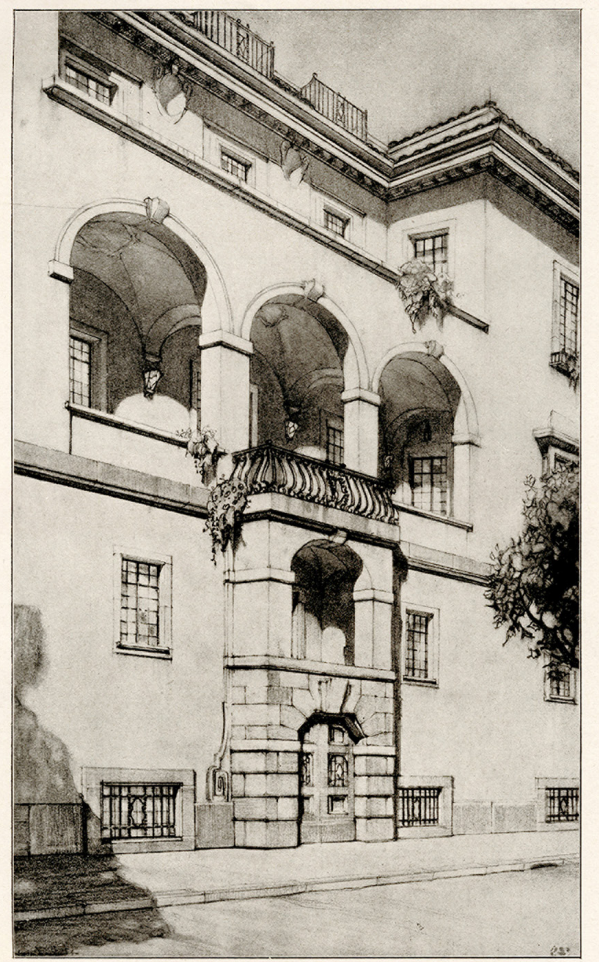

PICCINATO: PROGETTO DI PALAZZO (LATO VERSO IL LUNGOTEVERE MARZIO)

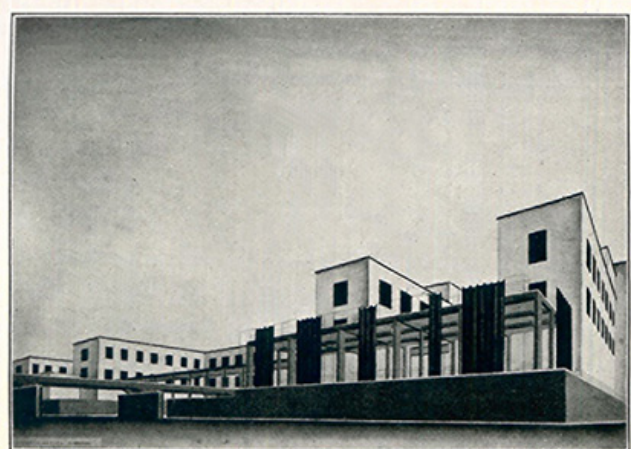

IL REFETTORIO.

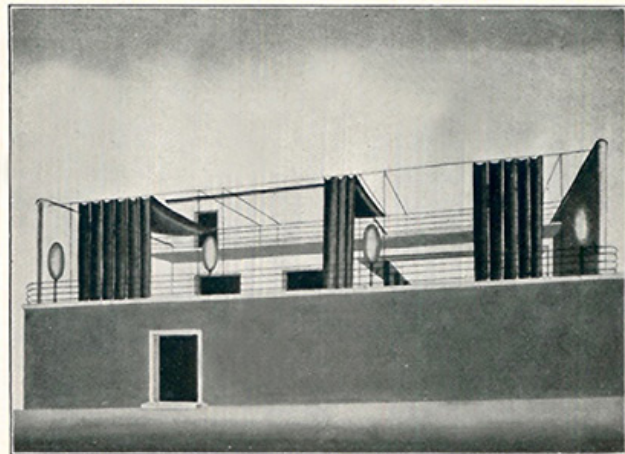

LA CASA DELLA DIRETTRICE
Fig. 9. Dalla tesi di laurea di Mario Ridolfi, A.A. 1928-29 [Architettura MCMXXX, p. 69]

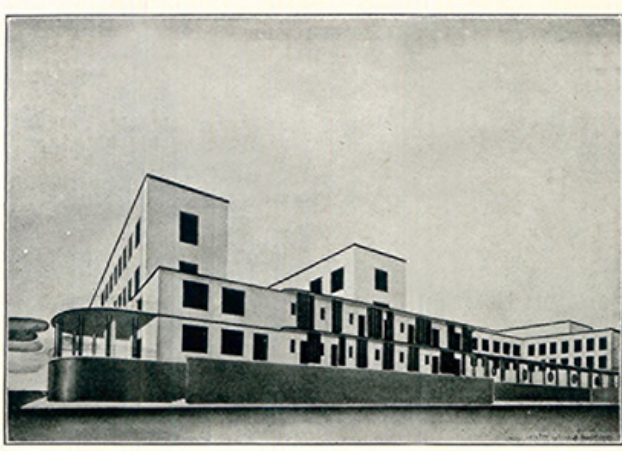

LA CASA DELLE INSEGNANTI

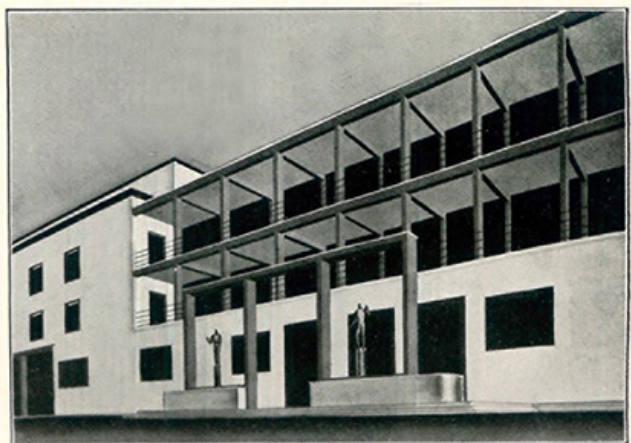

INGRESSO PRINCIPALE 
Fig. 10. Mario Paniconi, tesi di laurea, A.A. 19281929 [Architettura e Arti Decorative, MCMXXX p. 8].

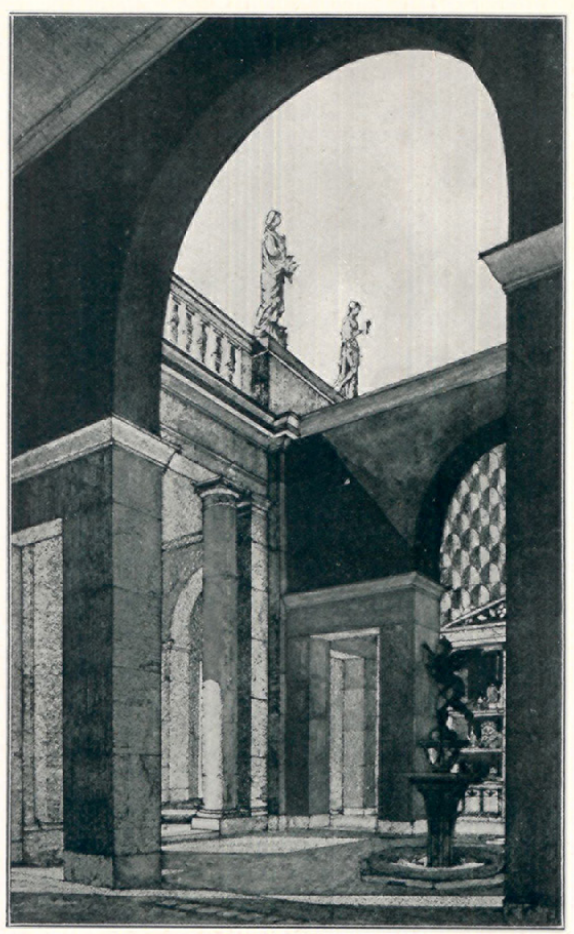

PROSPETTIVA DEL CENTRO DEI NEGOZI. ARCH. MARIO PANICONI: PROGETTO DI SISTEMAZIONE DELLA NUOVA FONTE GIÀ "ANTICOLANA" A FIUGGI.

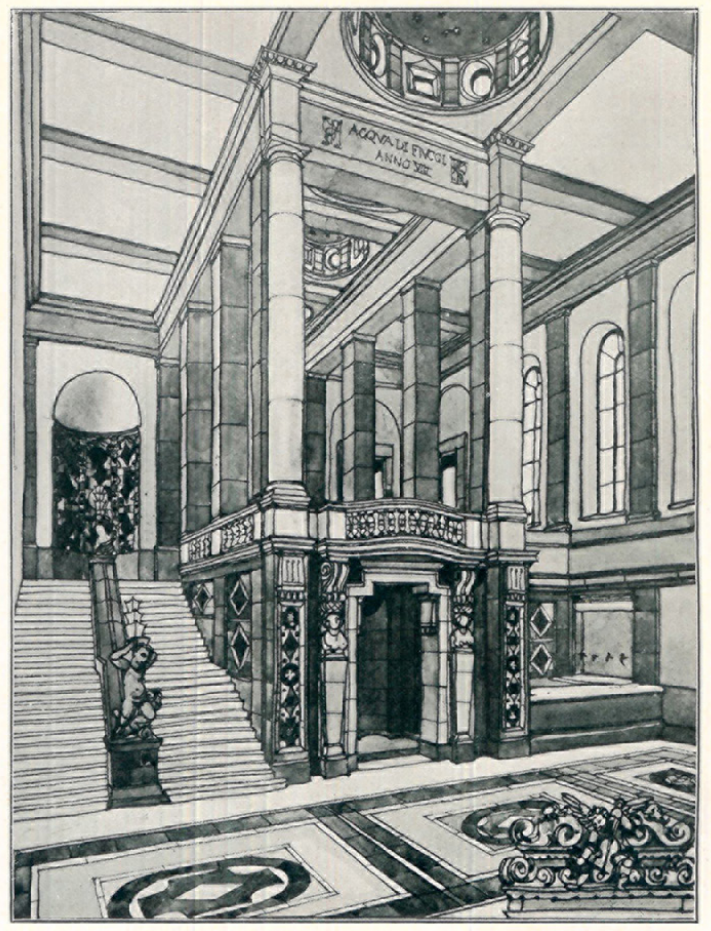

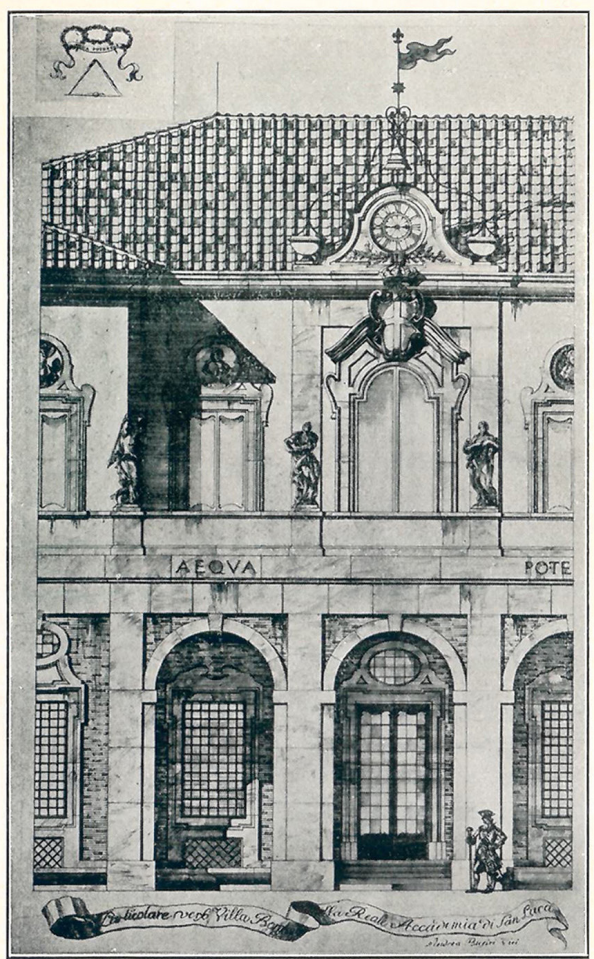

ARCH ANDREA BUSIRI VICI, DETTAGLIO DEL PROGETTO DELIA

REALE ACCADEMIA DI S. LUCA A VALLE GIULIA.
FIg. 11. Andrea Busiri VICl, rea, A.A. 1928-29 [ArchiMCMXXX, p. 88] 
ha messo a punto la lettura dell'architettura antica e moderna attraverso il ridisegno e la scomposizione grafica per riconoscervi tracciati regolatori, sezioni auree, rettangoli dinamici, partizioni notevoli, la presenza di proporzioni musicali, moduli e griglie modulari, di regole della composizione grafica mediante simmetrie semplici e complesse, iterazioni, bilanciamenti (fig. I2). Un nobile patrimonio della vecchia accademia che, riteniamo innegabilmente, offriva la possibilità di leggere, attraverso opportuni metodi di analisi coerenti con le forme da indagare, le configurazioni formali antiche e in parte quelle moderne. L'individuazione, la raccolta documentaria, la classificazione, unitamente alla lettura critica delle documentazioni grafiche prodotte in ambito professionale dai docenti, ed in ambito accademico dai discenti, riteniamo possano offrire l'opportunità di una inedita e perciò originale rilettura interpretativa degli esiti di un particolare ed unico periodo della nostra recente storia.
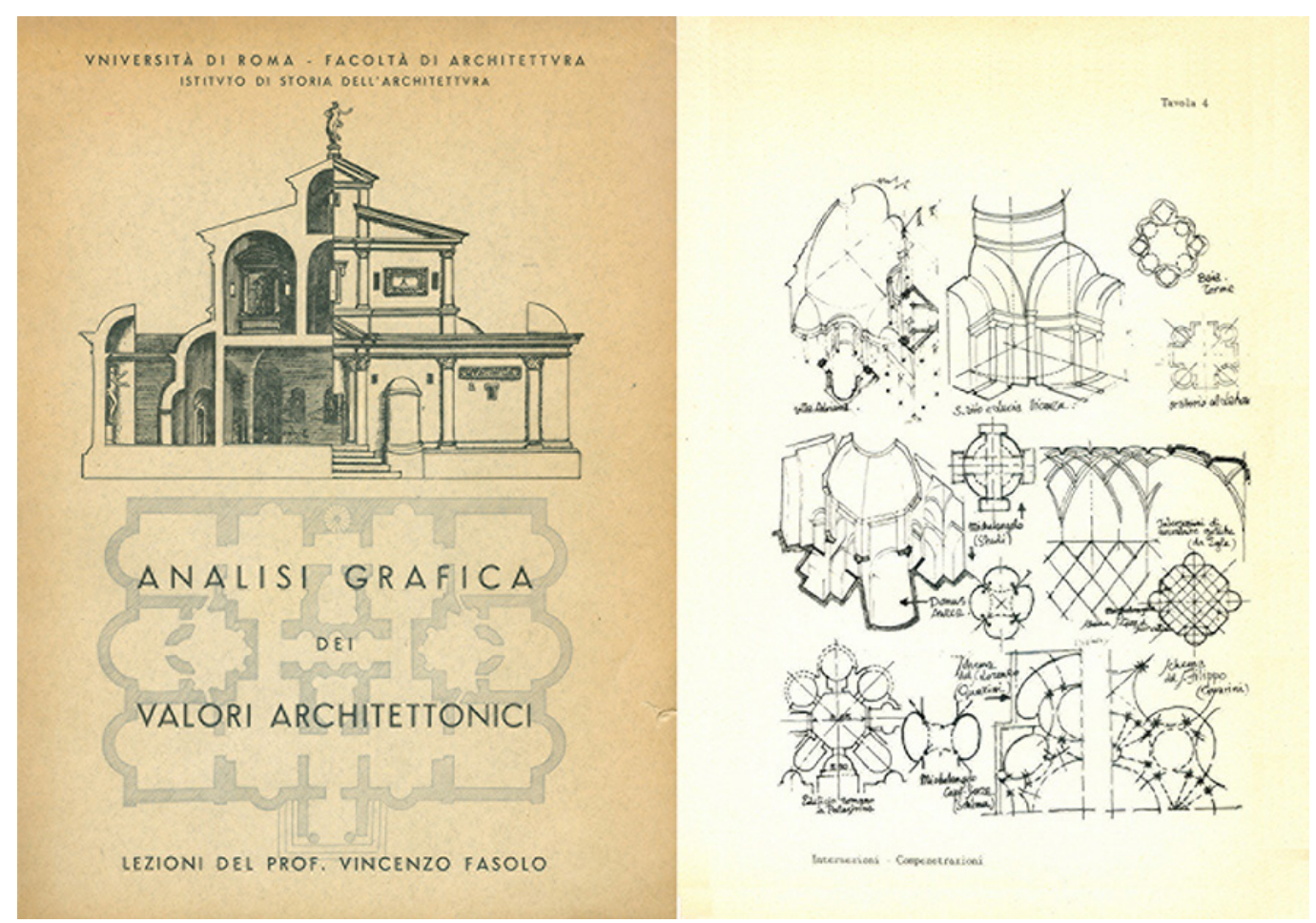

Note

[I] Giovanni Rosadi Avvocato, Sottosegretario di Stato della Pubblica Istruzione in più governi tra i quali quello di Salandra II al quale nello specifico è riferito l'intento.

[2] Gustavo Giovannoni proponeva già nel 1907 la formazione della figura dell'"architetto integrale", per maggiori approfondimenti si veda: Strappa 1995, p. 12

[3] In merito al Prof. P. Santini si veda: D'Amato 2017, p. 43.

[4] Luigi Cremona Matematico Senatore del Regno d'Italia a partire dalla XIII Legislatura, ebbe un ruolo significativo nella riforma dell'istruzione.

[5] Affermazione di Luigi Cremona. Si veda: Giovannoni 1932, p. 12.

\section{Riferimenti bibliografici}

Architettura e Arti Decorative, MCMXXIV-MCMXXV, Anno IV,Volume Primo, Milano-Roma: Casa Editrice d'Arte Bestetti e Tumminelli.

Architettura e Arti Decorative, MCMXXX, Anno X, Fasc. II - Ottobre, Milano-Roma: Casa Editrice d'Arte Bestetti e Tumminelli.

Associazione artistica fra i cultori di architettura, 1929. Annuario: 1925- 1928, Roma:Tipografia cooperativa sociale. 1929. 
Bompiani Enrico (1928). Lezioni di Geometria descrittiva. Roma: Stabilimento Tipo-Litografico del Genio Civile. Fig. 9, p. 187.

Chiavoni Emanuela (20/4). Drawings on Paper. Digital Historical Archives of the former Radaar Department at the University Sapienza School of Architecture in Rome. In SClentific RESearch and Information Technology. Ricerca Scientifica e Tecnologie dell'Informazione. Vol 4, Issue 2 (20 I4), pp. I I7- 126.

Cimbolli Spagnesi Piero (2016). Disegno e mestiere. La formazione dell'architetto a Roma prima della fondazione della Scuola Superiore di Architettura, 1873-1914. In Barbieri Costanza. The Lost Art of Drawing - L'arte perduta del disegno, catalogo della mostra. Roma: L'Erma di Bretschneider. pp. 27-56.

Cimbolli Spagnesi Piero (2018). Fino a La Sapienza. Fondamenti normativi dell'insegnamento dell'architettura a Roma e in Italia, I87| - 1935. In Quaderni dell'Istituto di Storia dell'Architettura, N.S. pp. 39-64.

Crevato-Selvaggi Bruno (a cura di), (20II). Vincenzo Fasolo dalla Dalmazia a Roma. Vita e opere dell'architetto spalatino. Lido di Venezia: La Musa Talia Editrice. 20 I I. Foto I.I.D. p.56.

D'Amato Claudio (2017). La Scuola di Architettura di Gustavo Giovannoni e la sua eredità oggi in Italia. In Bollettino del Centro di Studi per la Storia dell'Architettura, I (N.S.), 20 I7. Roma: Edizioni Quasar. 33-46 pp.

Diemoz Luigi (1936). Moretti architetto. Prepositi di artisti. In Quadrivio, 3, 13 dicembre 1936, p. 5.

Franchetti Pardo Vittorio (a cura di), (200I). La Facoltà di architettura dell'Università La Sapienza dalle origini al Duemila: discipline, docenti, studenti. Roma: Gangemi Editore.

Giovannoni Gustavo (1925). Discussioni didattiche. Questioni di Architettura nella Storia e nella Vita: Edilizia-Estetica architettonica-Restauri-Ambiente dei Monumenti. Roma: Società Editrice di Arte lllustrata.

Giovannoni Gustavo (a cura di). (1932). La Scuola di Architettura di Roma. Roma: Paolo Cremonese Ed. I932. XI E.F.

Mezzetti Carlo (1989). Rappresentazione e linguaggio architettonico: la "Scuola Romana" negli Anni Trenta. In Disegnare. Idee immagini, 0, 1989, pp. 25-36.

Piacentini Marcello (192 I). II momento architettonico all'estero. In Architettura e Arti decorative, Fascicolo I Maggio-Giugno, I92 I, pp. $32-76$

Purini Franco (2004). La formazione degli architetti romani negli anni Sessanta. In Rassegna di Architettura e Urbanistica, n. I I 2 - I I 3I |4, gennaio dicembre 2004, XXXVII, pp. 335.

Severi Francesco (1936). Applicazioni di Geometria descrittiva. Lezioni del prof. F. Severi; raccolte da Michele Campanella. Roma: G.U.F. di Roma.

Scuola Superiore di Architettura 1931-33. Annuario della Regia Scuola Superiore di Architettura di Roma.

Strappa Giuseppe (1995). Unità dell'organismo architettonico. Note sulla formazione e trasformazione dei caratteri degli edifici. Bari: Edizioni Dedalo.

Vagnetti Luigi, Dall'Osteria Graziella (a cura di). (1955). La Facoltà di Architettura di Roma nel suo trentacinquesimo anno di vita: anno accademico 1954-55. Roma: Officina.

\footnotetext{
Autori

Laura Carnevali, Sapienza Università di Roma, laura.carnevali@uniromal.it

Marco Fasolo, Sapienza Università di Roma, marco.fasolo@uniromal.it

Fabio Lanfranchi, Sapienza Università di Roma, fabio.lanfranchi@uniroma l.it
}

Per citare questo capitolo: Carnevali Laura, Fasolo Marco, Lanfranchi Fabio (2020). II Disegno e la Scuola Superiore di Architettura/Drawing and the Advanced School of Architecture. In Arena A., Arena M., Brandolino R.G., Colistra D., Ginex G., Mediati D., Nucifora S., Raffa P. (a cura di). Connettere. Un disegno per annodare e tessere. Atti del $42^{\circ}$ Convegno Internazionale dei Docenti delle Discipline della Rappresentazione/Connecting. Drawing for weaving relationships. Proceedings of the 42 th International Conference of Representation Disciplines Teachers. Milano: FrancoAngeli. pp. 238-259 


\title{
Drawing and the Advanced School of Architecture
}

\author{
Laura Carnevali \\ Marco Fasolo \\ Fabio Lanfranchi
}

Abstract

The Advanced School of Architecture was instituted in Rome in 1919, with inauguration in 1920, and would be key in finally delineating a precise professional profile, that of the architect. A heated international debate characterizing the multitude of opinions in the nineteenth century ranged from supporters of academic drawing tied to the Ecole des Beaux-Arts and those who defended the fundamentals of geometric drawing in the name of technical instruction spread by the Ecole Politechnique. In Italy, at least, the debate therefore found a useful reference for redefining a figure whose precise role had begun to be lost with the advent of the eighteenth century. The writings of Gustavo Giovannoni, a premier authority on the official culture of architecture in this period, illustrate the characteristics of this 'new professional figure', a figure that the new School of Architecture in Rome aimed to educate: 'the complete architect'. As stated by Giovannoni and fully shared by other masters in the world of architecture of the period, this figure should possess complete cultural expertise in the areas of art, science, and history -as much as it pertains to art and architecture- as well as specific competence related to construction and administration. The present contribution provides a preview of ongoing research regarding the teaching of drawing in the first decades after the inauguration of the Advanced School of Architecture in Rome.

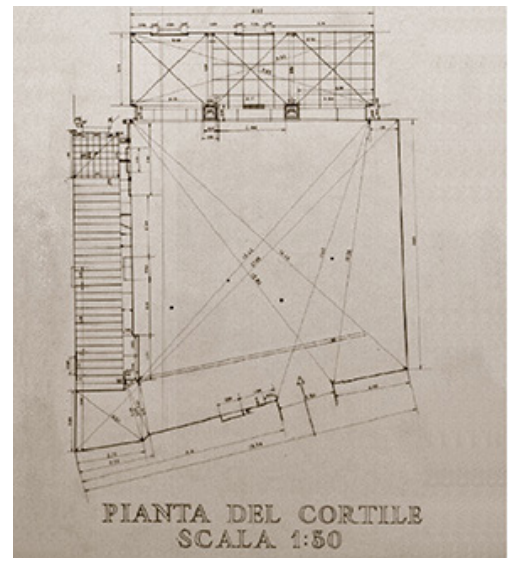

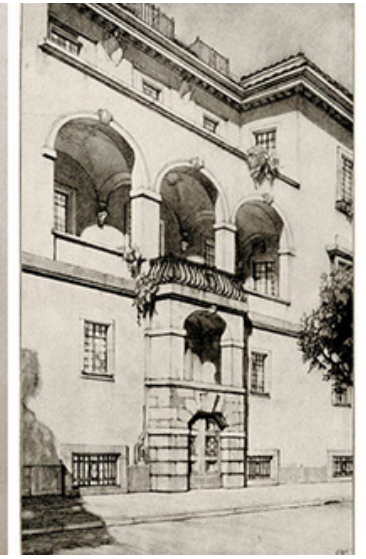

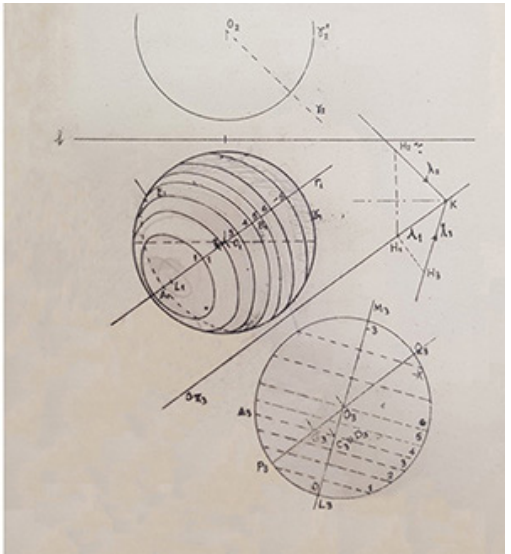

doi.org/ | 0.3280/oa-548. I5 


\section{Background and cultural climate: the $(\mathrm{Re})$ birth of the complete architect}

In early twentieth-century artistic environments, the nineteenth-century tradition and academic teaching were tending towards a new culture of modernity and, by the end of the 1910s, all figurative art began to feel the new cultural ferment that was largely influenced by European art. Italian architecture and the culture of design, however, seemed to resist cultural trends originating beyond the Alps. As Marcello Piacentini stated in a 1921 article published in Architettura ed Arti Decorative:'We are still [... in the hearty architectural middle class, which parades a non-existent richness [...] We are still producing architecture typical of presumptuous foremen [Piacentini 1921, p. 75]. He defined architectural drawing of the period as falling 'under the cloak of the stereotypical stylism' [Piacentini 1921, p. 75].

Thanks to the work of young architects, at the end of the 1920s, graphical language was simplified, expressing a new architecture capable of engaging with new European trends. Fervent transformations matured in this climate and with regard to architecture, there was an increasingly pressing need to train a new professional figure whose teachings would descend from an organization different from the two institutions appointed for training. The first was the Fine Arts Academies, where artistic studies lacked technical and also partially cultural content. The second was the Engineering Schools, where architecture was considered a branch of construction and therefore far removed from a united concept from which a capacity for synthesis could grow to create buildings that were useful but also well defined and an expression of harmonic thought.

For about thirty years, the debate about architectural teaching in Italy was fervid, but impassioned discussions on the topic could not produce any practical results. The merger of the two forms of teaching into a single school occurred for the first time in 19/4 at the hand of Giovanni Rosadi [ I], but it was a failure, even if it succeeded in raising public awareness about the problem. The Advanced School of Architecture was instituted (the first in Italy) in 1919 and inaugurated in 1920, based on which the profile of the new professional was delineated. The writings of Gustavo Giovannoni, a maximum authority on the official culture of architecture of the period (professor of architecture at the Royal School of Engineering in Rome, director of the Advanced School of Architecture in Rome, and instructor of the

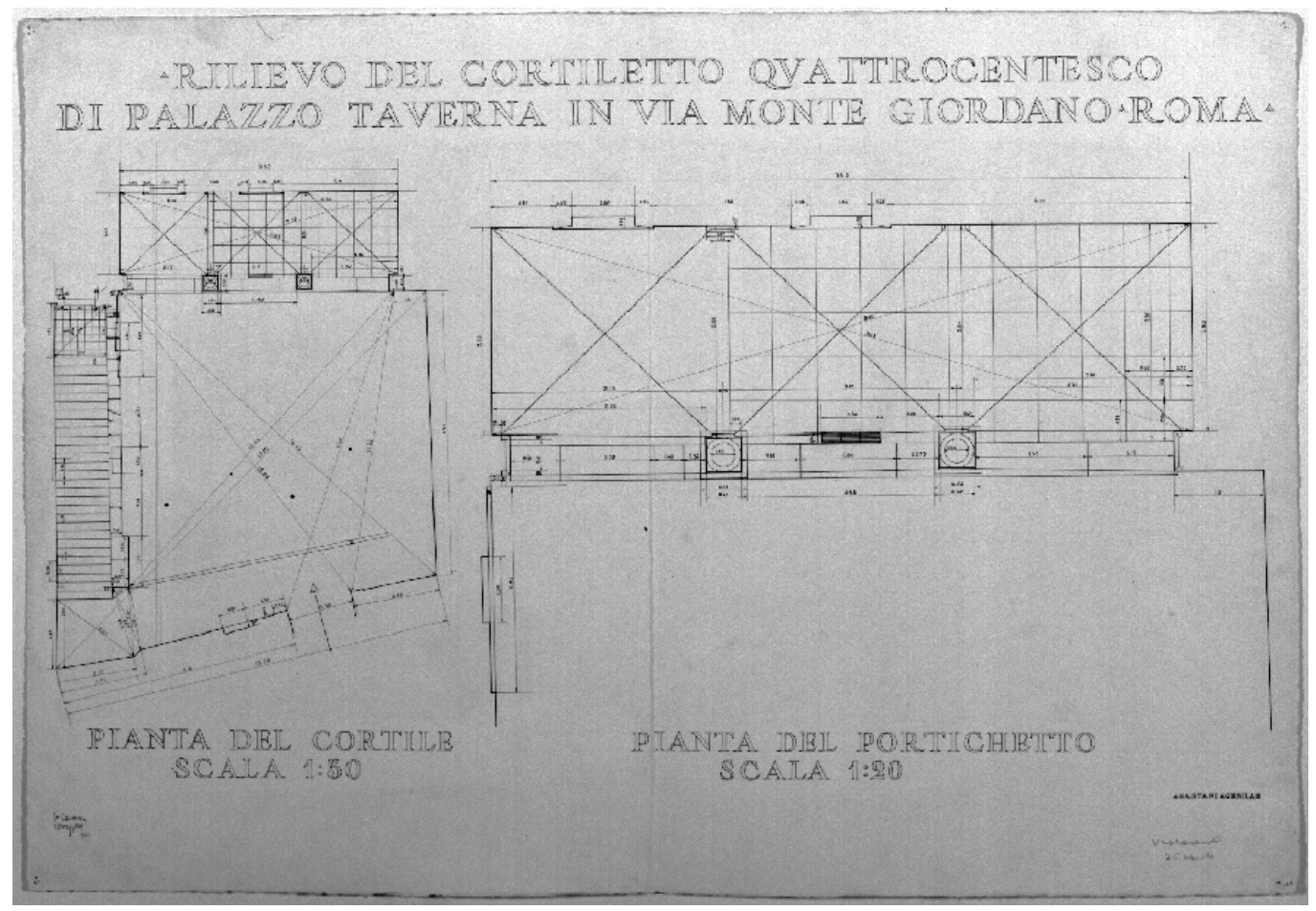


restoration of monuments), outline the characteristics of the professional figure -'the complete architect'- [2] that the new School of Architecture in Rome set as its goal to educate. As stated by Giovannoni, but shared by other masters in the world of architecture, this figure should possess complete cultural expertise, solid artistic preparation, adequate scientific preparation, a knowledge of the history of art and architecture, as well as experience related to problems regarding construction and administration.

In this new context, drawing became a key element, characterized by abundant practice through sketches, notebooks on the most diverse subjects, surveying exercises (figs. I, 2), and even drawings made from real life (figs. 3,4) and photographs. While education today is still far from teaching drawing as such, it is a means and transdisciplinary tool that plays an absolutely decisive role in all disciplines in which it is practiced in the School. The educational and communicational value of drawing was held in high esteem by the 'architects' brought together by Giovannoni in 1920 in the close quarters of the Fine Arts Academy in Via di Ripetta, the provisional site of the School, who discussed, even animatedly, the cultural direction that the new institution should take. Manfredo Manfredi, Giulio Magni, Giovan Battista Milani, Fausto Vagnetti, Marcello Piacentini, Arnaldo Foschini, Vincenzo Fasolo, and P. Santini formed part of this group. Many of these were members of the Artistic Association among architecture enthusiasts and, beginning in the first academic year 1920-1921, served as instructors in the subjects most pertinent to them according to their undisputed skills.

\section{From 'Ferro di Cavallo' to 'Royal Advanced School of Architecture, a path followed through a clear drawing}

Nineteen thirty-two marked an important year for the school: the new Valle Giulia campus was inaugurated based on a project by Del Debbio. Three years later, the school would leave the post to the Faculty of Architecture (fig. 5). The teachings planned for academic year 1931 - 1932, which were divided into four teaching cycles - scientific/technical; artistic; historical/artistic; architectural- were designed to train a professional figure capable of connecting artistic and scientific studies, synthetically defining the complete architect.

Fig. 2. Course in Elements of Architectural and Monumental Surveying Faculty of Architecture. R. Colella student, I950s (Drawings Archive of Department of History, Representatrion and Restoration of Architecture Sapienza University of Roma).

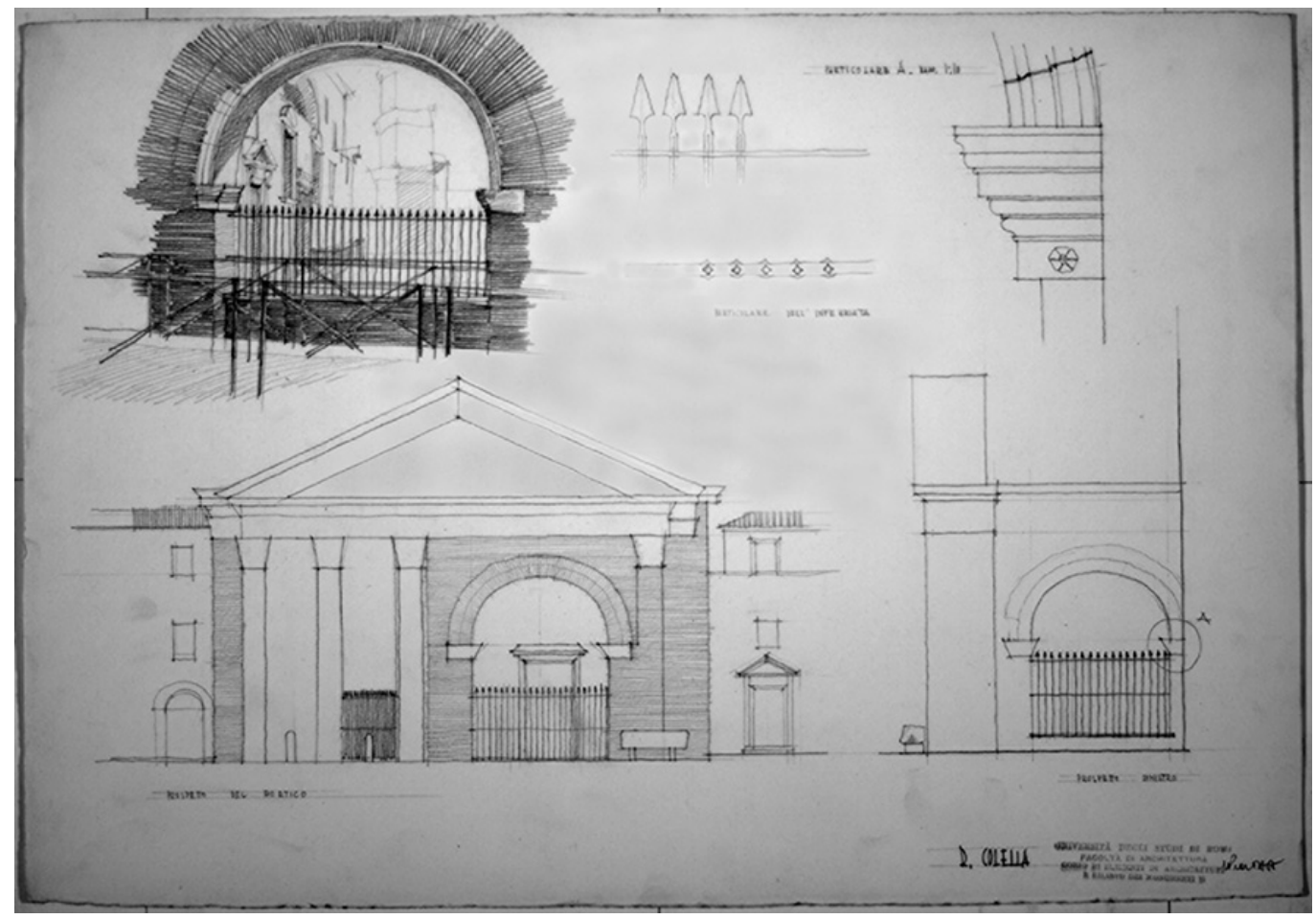


The instructors called to teach these subjects were identified from among those who, for their clear cultural capacity, would have lent prestige to the teachings entrusted to them. Among others, we recall Ugo Amaldi for Mathematical analysis, Enrico Bompiani for Descriptive geometry (fig. 6), Vincenzo Fasolo for Architectural history and styles, Giuseppe Boni for Construction elements, Luigi Vagnetti for the Design of ornamentation and figures, Enrico Del Debbio for Architectural drawing and elements of composition, Francesco Severi for Applications of descriptive geometry (fig. 7), Gustavo Tognetti for Monument surveying, Giulio Ferrari for Pictorial decoration, Giovanni Prini for Ornamental sculpture, Arnaldo Foschini for Architectural composition, Vittorio Morpurgo for Interior design and decoration, Giovanni Battista Milani for Construction techniques, Giovanni Cicconetti for Topography and road construction, Marcello Piacentini for Building and garden art, Gustavo Giovannoni for Monument restoration and Vittorio Grassi for Scenography.

Reading these names, we recognize many of the great masters that characterized the architecture of the period with their work. In the graphics for their projects, it is difficult to discern the compositional aspects from the representational ones, poetry from prose. In 1936, Luigi Moretti stated in Quadrivio, "graphical conception is the natural way to express contemporary architecture. Today, the construction is a pure and simple projection of the graphic rather than, as the graphic should be and always has been, a projection of the construction" [Diemoz 1936, p. 5]. The drawing was therefore masterfully configured in that period not only as an expressive means, but also for internal reflection to understand the architecture as already built and to experiment with, verify, and communicate one's own design ideas. And if this is true, as is true, that this concept of drawing was strongly rooted in the thought of teachers at the time -all talented designers- we should not be surprised that the 'practice' of drawing was very present in all teachings that would have formed the complete architect that was so dear to Giovannoni.

Drawing therefore assumed the role of a necessary cultural medium in which the teaching of concepts imparted during the lessons was concretized thanks to said medium. It is enough to flip through the texts of the teaching programmes presented in those years and follow them to find explicit references to drawing among the various arguments exclusive to each subject. These references are also testified to by the fine graphical panels produced by students to

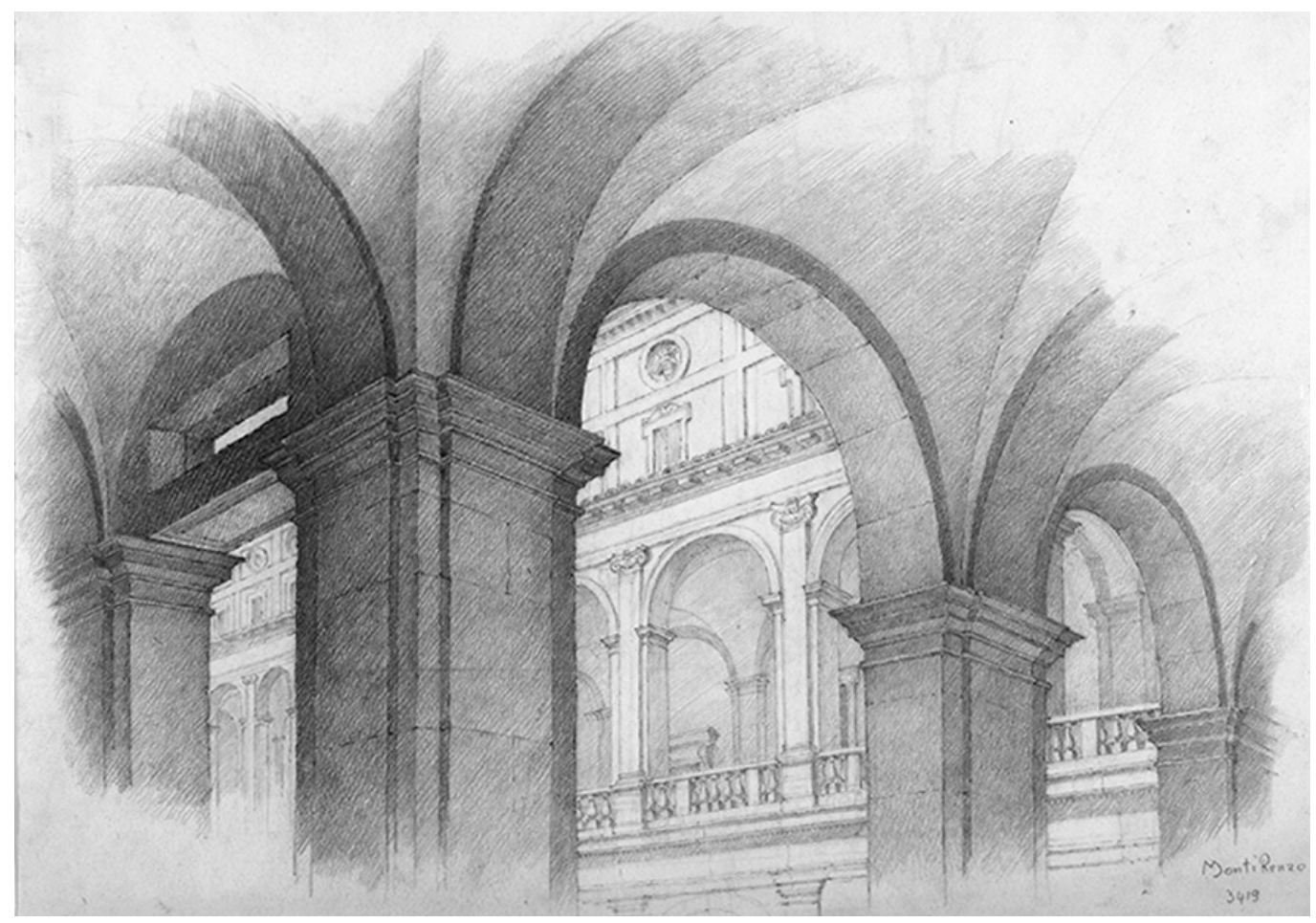


Fig. 4. Exercise of Life Drawing. Fedele Savoia student, seria number 26/2, year 1947 (Drawings Archive of

Department of History,

Representatrion and Re-

(toration of Architecture,

Sapienza University of

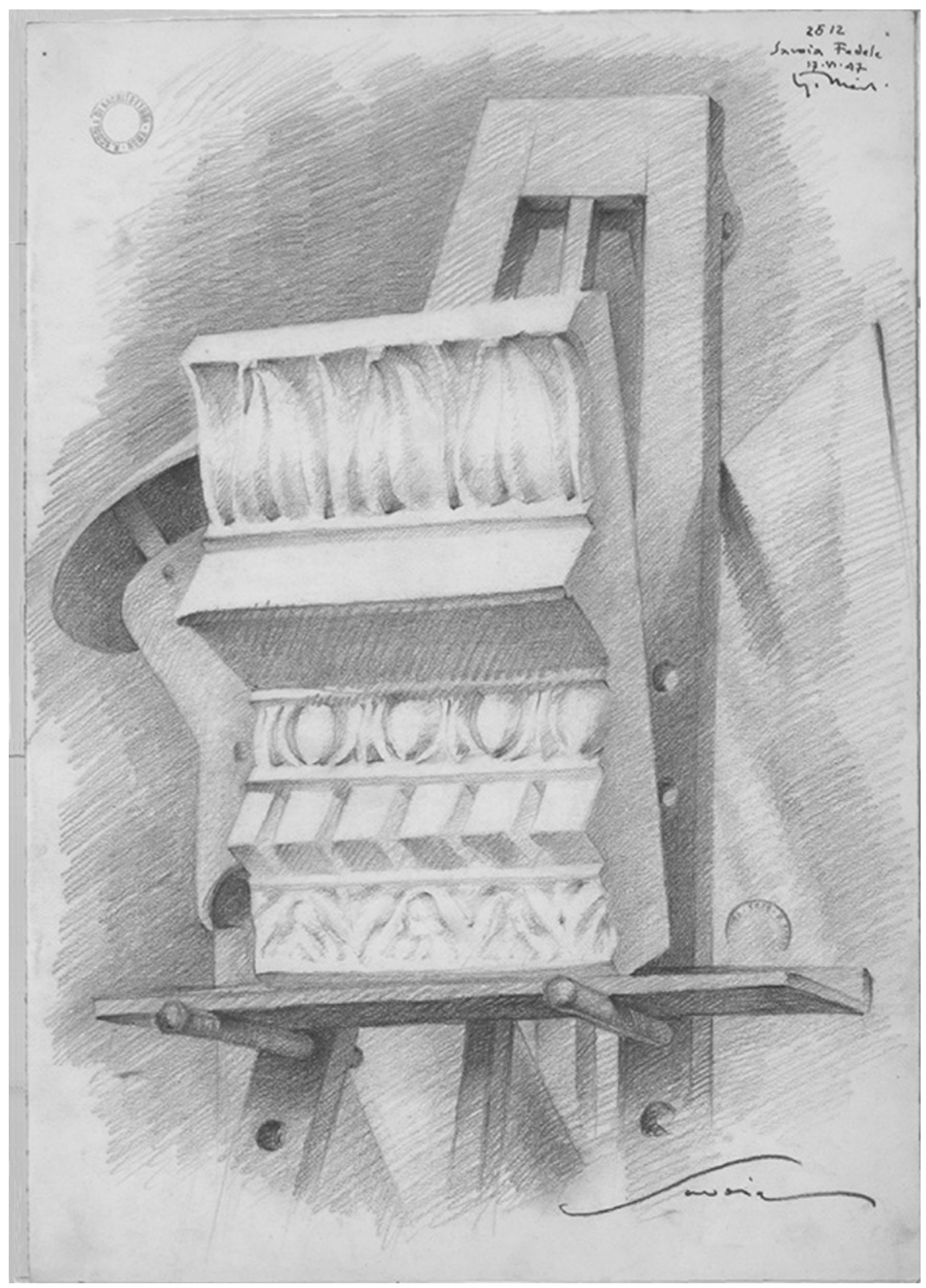


accompany the educational objectives of the individual courses. For necessary brevity, we report some citations present in the 1954-1955 annual report relative to precisely the artistic component of drawing present in some courses: "Elements of Architecture and Surveying of Monuments and Drawing from Real Life, both two-year courses. In the first, the student, by surveying existing buildings, beginning the habit of bringing drawing together with objects and acquiring a sense of the 'measurement' of things, $[\ldots]$ begins to acquire the capacity to translate his or her own thought into lines. In the second, the student is trained in the rapid representation of objects in shaded perspective in their natural environment and in doing so is made aware of the particular importance that the play of light and atmosphere and their variations have on the final aesthetic result of a building" [Vagnetti, Dall'Osteria 1955, p. I4]. These teachings are accompanied by those of Descriptive geometry and Elements of projection and its applications, "which provide a theoretical foundation and therefore a more precise practical tool, to correctly represent what the eye sees or fantasy suggests" [Vagnetti, Dall'Osteria 1955, p. I4]. Together with these subjects comes the course in Sculpture, which "accustoms young people to controlling the relationship between the shapes as conceived and their real effect" [Vagnetti, Dall'Osteria 1955, p. I 4].

The primacy of the drawing in its worth as a means of cognition and communication was widely recognized and practiced in nearly all courses. With regard to the importance of teaching students to master this tool, we again cite Giovannoni when recalling Luigi Cremona's warning [4]: "no cultured person should be allowed to ignore drawing" [5]. In our opinion, Giovannoni's teaching structure, or the idea of drawing in the School, began to crack and finally dissolve in three distinct historical moments in the twentieth century: the 1960s with the student movement, the 1980s with the university reform, and the 1990s with the now widespread computer revolution.

\section{Critical considerations}

That being said, and considering the rather synthetic general framework on the state of the art in the subject, the development of the research, situated within the general area of the School of Architecture of Rome, was aimed precisely at the area of teaching related to drawing. In particular, the goal was to 'penetrate' the tangle of teaching provided by the

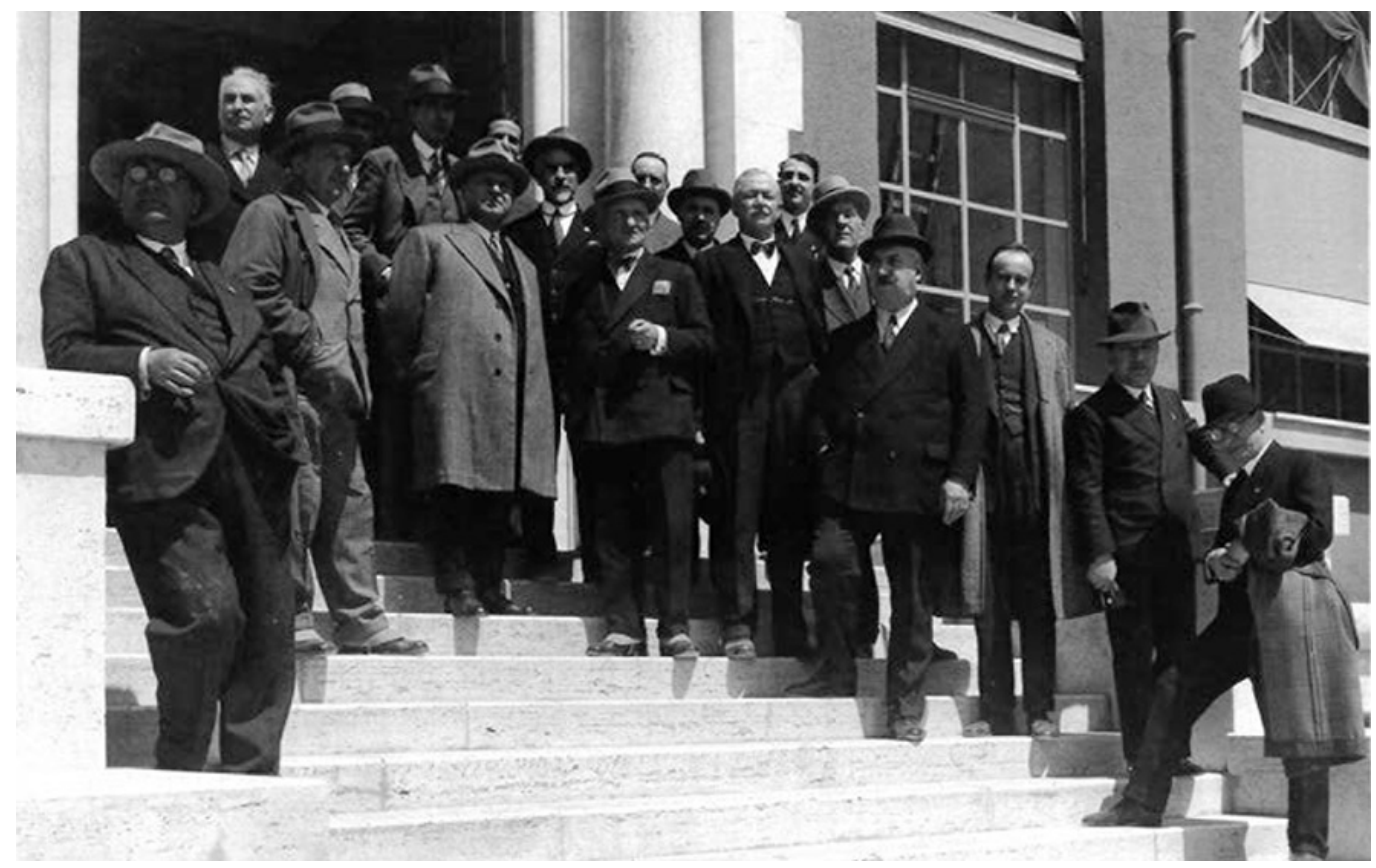


founding masters of the school up to the virtual moment at which the next generation was introduced. We consider that the scientific value of this examination may hold particular importance even though, as mentioned above, it is not possible to frame drawing in that specific context with the current disciplinary independence that would become the norm only many years after the school was founded. The school, therefore, was solidly imprinted on drawing still intended as a common denominator for performing that articulated artistic and professional activity known as architecture.

Fig. 6. Enrico Bompiani, 1928, Hyperboloid

Bompiani 1928, pag. 187 fig. 9].

Fig. 7. Francesco Severi 936, Sphere isophote [Severi 1936, p. 223]
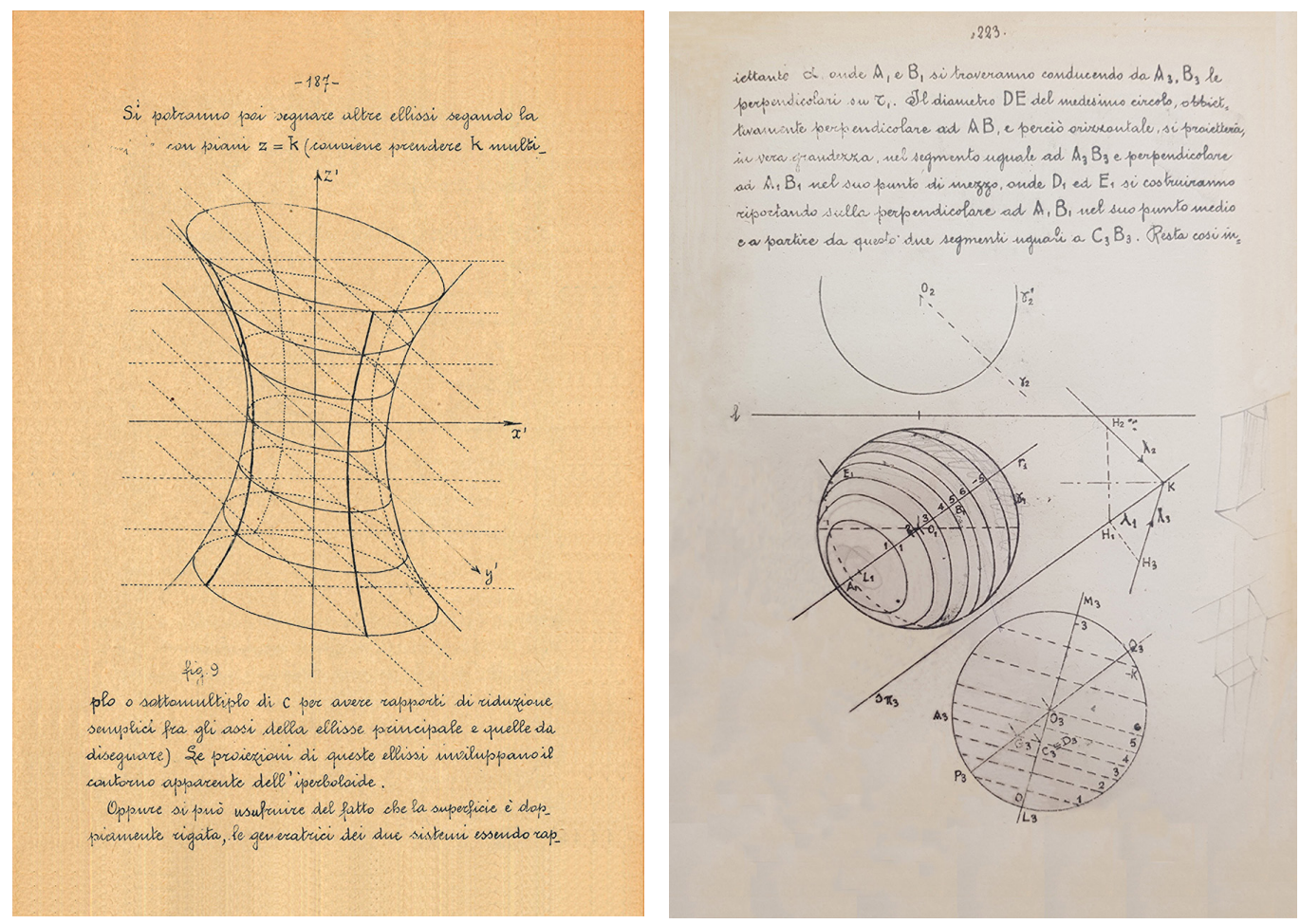

The 'transversality' of Drawing, it should be noted, did not lead misunderstanding from the operational point of view; indeed, the graphical means was used with absolute propriety and pertinence according to the use. Ultimately no distinction was made between Drawing intended as a specific expressive activity, drawing as a cultural tool of knowledge, and Drawing as a function of an architectural process. Artistic drawing and technical drawing converged in the newborn School with their relative 'languages', but without a need to assign particular subjects and instructors with the task of transmitting the related 'linguistic' rules. The founding fathers of the Advanced School of Architecture of Rome therefore seem rather distanced from the complex developments of the second half of the 1960s related to the models of linguistics applied to architecture or rather semiology. The theses of Koenig, Eco, or De Fusco, as well as many other scholars, were capable of unveiling the processes of meaning in architecture, accepting from the verbal model what could be applied to the architectural sign and running into the difficulty of recognizing the meaningful element, on the scale of phoneme and word, and its meaning. Such theses reconsidered, perhaps in advance, the process of division into definite, rigorous specialized compartments that would come to light at the beginning of the 1980s.

We maintain that language was very present in the doctrine spread by the School's founders, but it lacked the burden of the mechanics of structuralism and its terminological rigidity, and the consequent declaration of adherence to a given school or author. In the numerous graphical examples by students who were certified at the time (figg. 8-II), the cultural 
Fig. 8. A drawing of Luigi Piccinato's degree thesis among the first graduates of the Schoo of Architecture [Architettura e Arti Decorative, MCMXXIV-MCMXXV p. 109].

Fig. 9. From Mario Ridolfi's degree thesis, A.y.1928-29] [Architettura e Arti Decorati

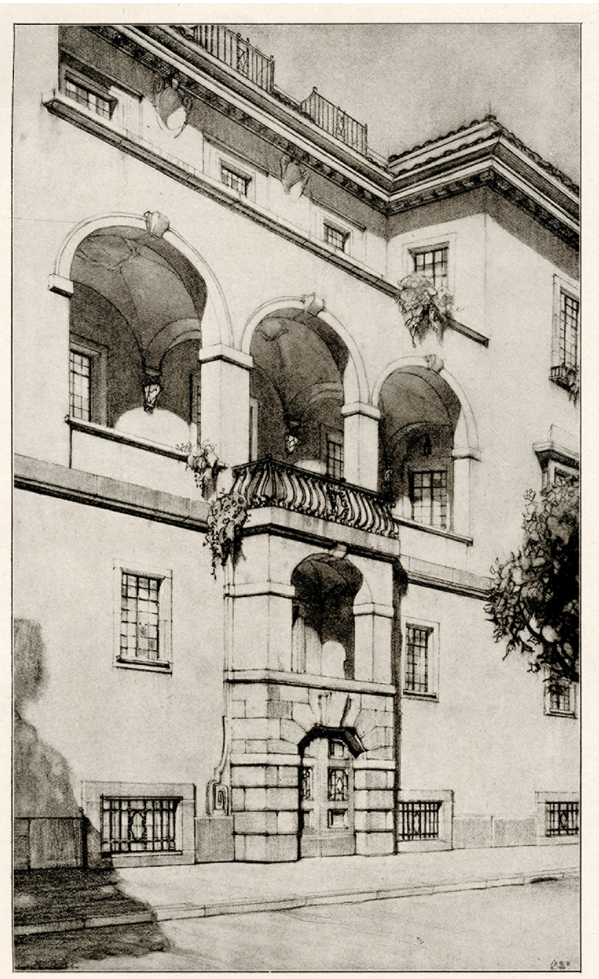

L. PICCINATO: PROGETTO DI PALAZZO (LATO VERSO Il LUNGOTEVERE MARZIO).

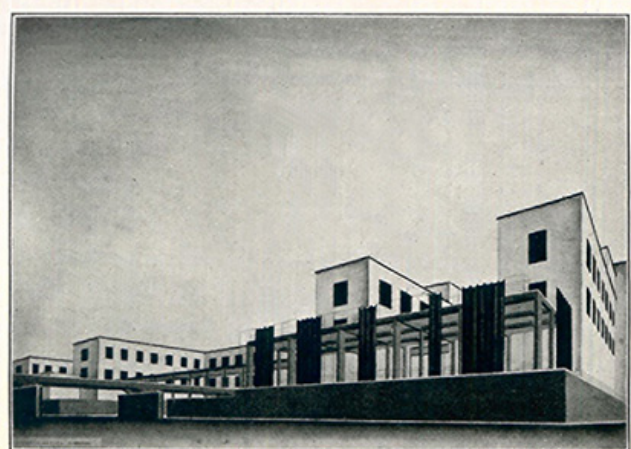

IL REFETTORIO.

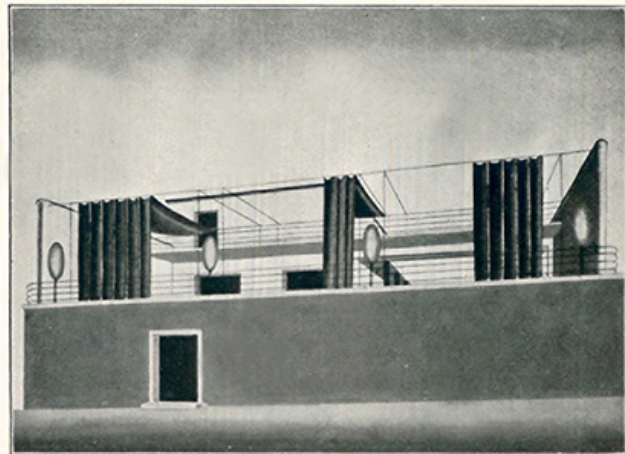

LA CASA DELLA DIRETTRICE

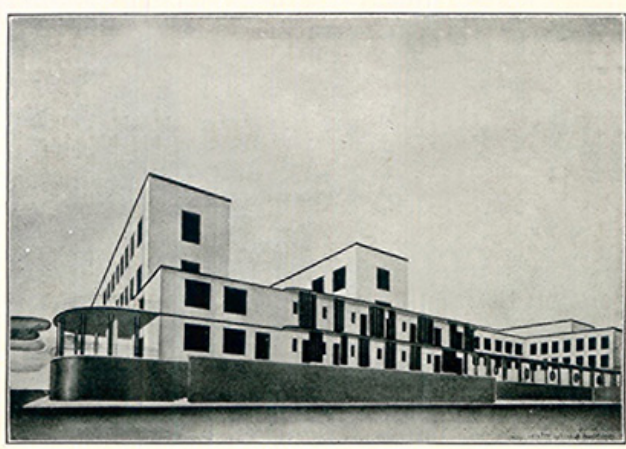

LA CASA DELLE INSEGNANTI

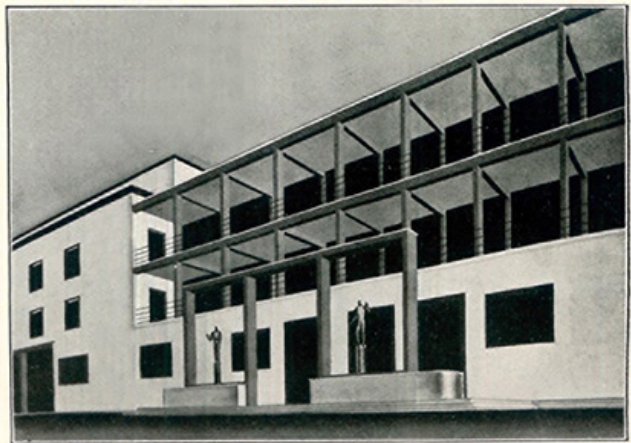

INGRESSO PRINCIPALE 
Fig. 10. Mario Paniconi, degree thesis, academic year 1928-29, A.y. 1928 29 [Architettura e Arti p. 8I].

Fig. I I. Andrea Busiri Vici, a sheet of his degree the sis, A.y. 1928-29 ArchiMCMXXX, p. 88].

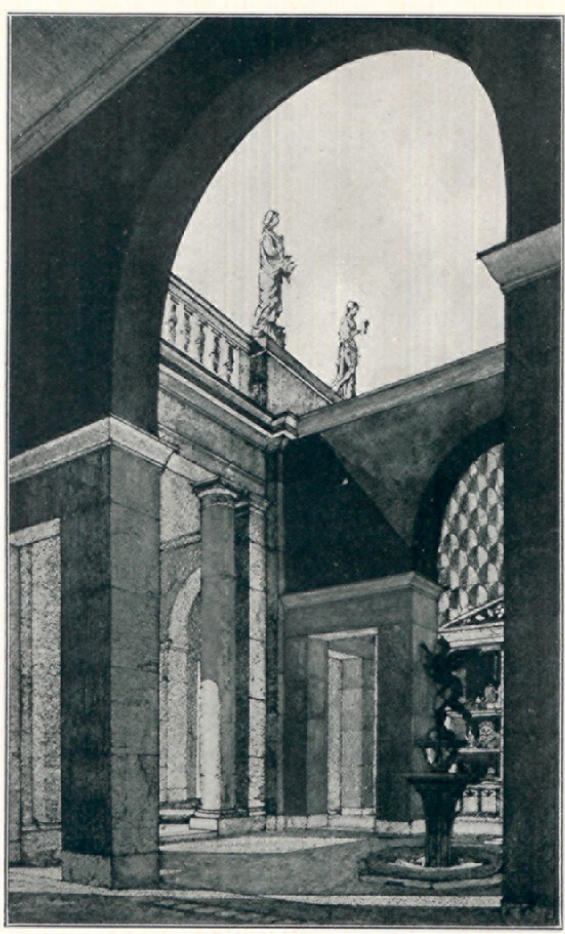

PROSPETTIVA DEL CENTRO DEI NEGOZI. ARCH. MARIO PANICONI: PROGETTO DI SISTEMAZIONE DELLA NUOVA FONTE GIÀ "ANTICOLANA" A FIUGGI.

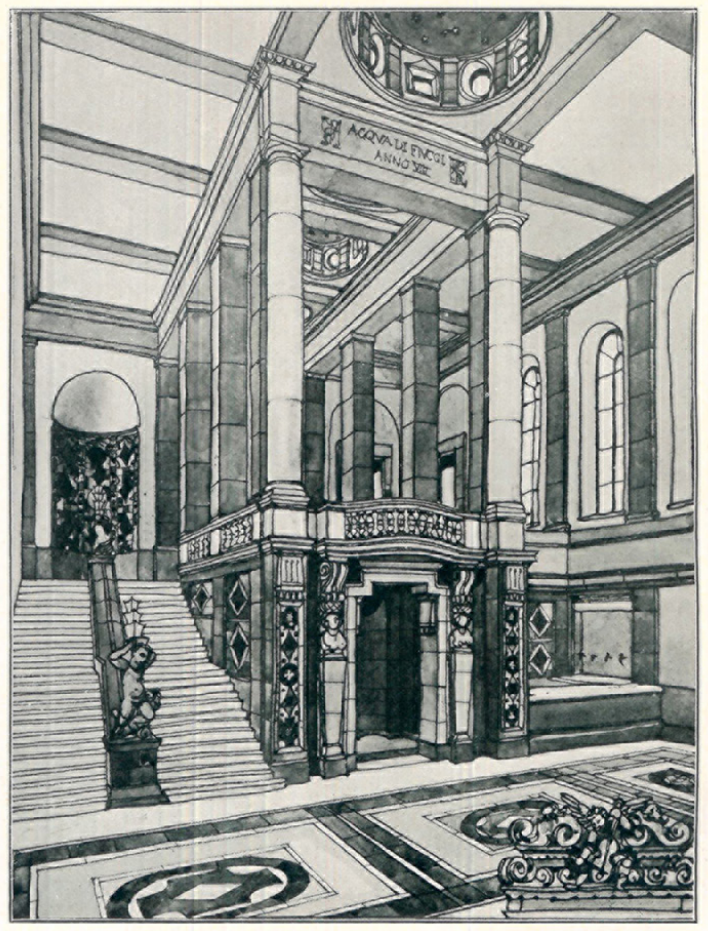

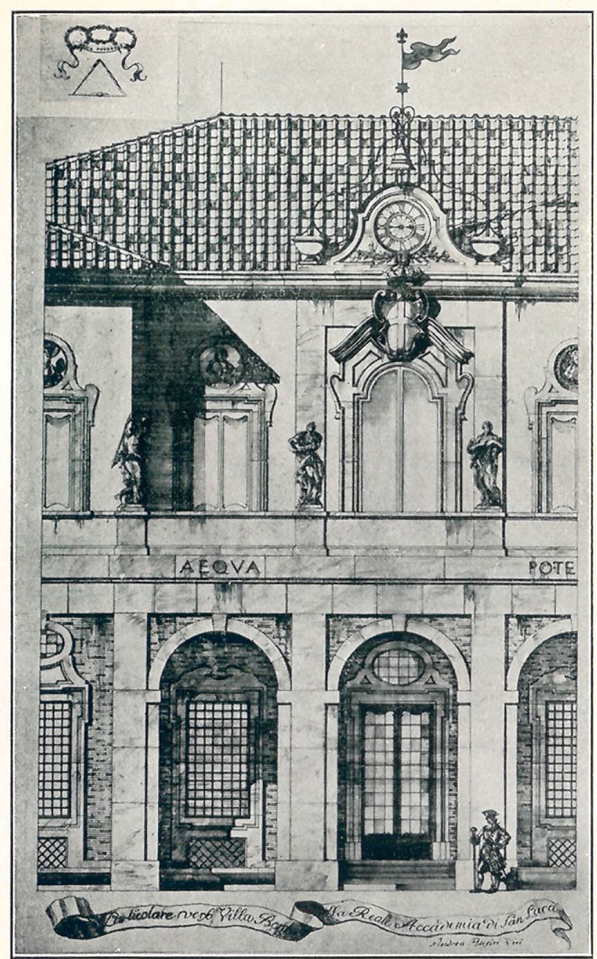

ARCH. ANDREA BUSIRI VICI: DETTAGLIO DEI PROGETTO DELIA

REALE ACCADEMIA DI S. LUCA A VALLE GIULIA. 
Fig. 12. Vincenzo Fasolo, Analisi grafica dei valori architettonici, s.d. (1955?) Università di Roma, Facoltà di Architettura. a) book cover;

b) plate 4 Intersections Interpenetrations. tradition of Rome in the field of graphical analysis flourished. From Vincenzo Fasolo on, the reading of ancient and modern architecture was developed via reworking and graphical decomposition to recognize their regulating traces, golden sections, dynamic rectangles, notable partitions, harmonic proportions, modules and modular grids, and the rules of graphical composition through simple and complex symmetries, iterations, and balancing (fig. 12). This is a noble heritage from the old academy that, indisputably in our opinion, offered the possibility to read the forms using appropriate and consistent methods of analysis to investigate ancient formal configurations and sometimes modern ones.

Identification, documentary research, classification, together with a critical reading of the graphical documentation produced by instructors in the professional sphere and by learners in the academic sphere, can offer the opportunity for a novel and therefore original interpretational rereading of the results of a particular and unique period of our recent history.
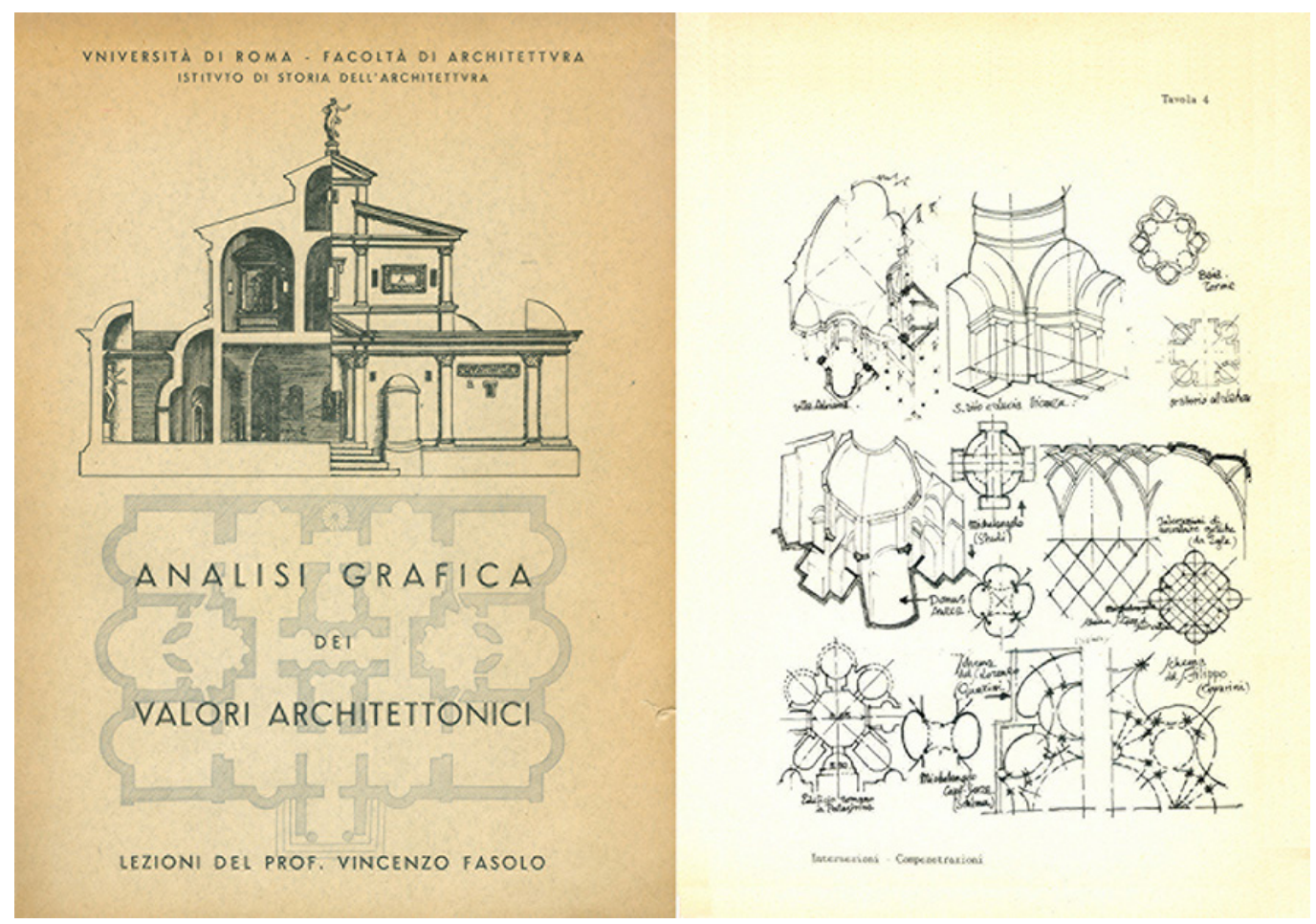

Notes

[I] Giovanni Rosadi, Lawyer, Undersecretary of State of Public Education in multiple governments, including under Salandra II, to which this particular intent refers.

[2] Gustavo Giovannoni had already proposed the formation of the 'complete architect' in 1907. For more information, see: Strappa 1995, p. 12.

[3] With regard to P.Santini, see: D'Amato 2017, p. 43.

[4] Luigi Cremona, Mathematician and Senator of the Kingdom of Italy starting with the I3th Legislature, played an important role in educational reform.

[5] Statement by Luigi Cremona, see: Giovannoni 1932, p. I2.

\section{References}

Architettura e Arti Decorative, MCMXXIV-MCMXXV, Anno IV,Volume Primo, Milano-Roma: Casa Editrice d'Arte Bestetti e Tumminelli.

Architettura e Arti Decorative, MCMXXX, Anno X, Fasc. II - Ottobre, Milano-Roma: Casa Editrice d'Arte Bestetti e Tumminelli.

Associazione artistica fra i cultori di architettura, 1929. Annuario: 1925-1928, Roma:Tipografia cooperativa sociale. 1929. 
Bompiani Enrico (1928). Lezioni di Geometria descrittiva. Roma: Stabilimento Tipo-Litografico del Genio Civile. Fig. 9, p. 187.

Chiavoni Emanuela (20/4). Drawings on Paper. Digital Historical Archives of the former Radaar Department at the University Sapienza School of Architecture in Rome. In SClentific RESearch and Information Technology. Ricerca Scientifica e Tecnologie dell'Informazione. Vol 4, Issue 2 (20।4), pp. I I7-I 26.

Cimbolli Spagnesi Piero (2016). Disegno e mestiere. La formazione dell'architetto a Roma prima della fondazione della Scuola Superiore di Architettura, I873-1914. In Barbieri Costanza. The Lost Art of Drawing - L'arte perduta del disegno, catalogo della mostra. Roma: L'Erma di Bretschneider. pp. 27-56.

Cimbolli Spagnesi Piero (2018). Fino a La Sapienza. Fondamenti normativi dell'insegnamento dell'architettura a Roma e in Italia, 1871 - 1935. In Quaderni dell'Istituto di Storia dell'Architettura, N.S. pp. 39-64.

Crevato-Selvaggi Bruno (a cura di), (20I I). Vincenzo Fasolo dalla Dalmazia a Roma. Vita e opere dell'architetto spalatino. Lido di Venezia: La Musa Talia Editrice. 20 I I. Foto I. I.D. p.56.

D'Amato Claudio (20 I7). La Scuola di Architettura di Gustavo Giovannoni e la sua eredità oggi in Italia. In Bollettino del Centro di Studi per la Storia dell'Architettura, I (N.S.), 20 17. Roma: Edizioni Quasar. 33-46 pp.

Diemoz Luigi (1936). Moretti architetto. Prepositi di artisti. In Quadrivio, 3, 13 dicembre 1936, p. 5.

Franchetti Pardo Vittorio (a cura di), (200I). La Facoltà di architettura dell'Università La Sapienza dalle origini al Duemila: discipline, docenti, studenti. Roma: Gangemi Editore.

Giovannoni Gustavo (1925). Discussioni didattiche. Questioni di Architettura nella Storia e nella Vita: Edilizia-Estetica architettonica-Restauri-Ambiente dei Monumenti. Roma: Società Editrice di Arte Illustrata.

Giovannoni Gustavo (a cura di). (1932). La Scuola di Architettura di Roma. Roma: Paolo Cremonese Ed. I932. XI E.F.

Mezzetti Carlo (1989). Rappresentazione e linguaggio architettonico: la "Scuola Romana" negli Anni Trenta. In Disegnare. Idee immagini, 0, 1989, pp. 25-36.

Piacentini Marcello ( I92 I). II momento architettonico all'estero. In Architettura e Arti decorative, Fascicolo I Maggio-Giugno, I92 I, pp. 32-76.

Purini Franco (2004). La formazione degli architetti romani negli anni Sessanta. In Rassegna di Architettura e Urbanistica, n. I I 2- I I 3I |4, gennaio dicembre 2004, XXXVII, pp. 335.

Severi Francesco (1936). Applicazioni di Geometria descrittiva. Lezioni del prof. F. Severi; raccolte da Michele Campanella. Roma: G.U.F. di Roma.

Scuola Superiore di Architettura 1931-33. Annuario della Regia Scuola Superiore di Architettura di Roma.

Strappa Giuseppe (1995). Unità dell'organismo architettonico. Note sulla formazione e trasformazione dei caratteri degli edifici. Bari: Edizioni Dedalo.

Vagnetti Luigi, Dall'Osteria Graziella (a cura di). (1955). La Facoltà di Architettura di Roma nel suo trentacinquesimo anno di vita: anno accademico 1954-55. Roma: Officina.

\section{Authors}

Laura Carnevali, Sapienza University of Rome, laura.carnevali@uniromal.it

Marco Fasolo, Sapienza University of Rome, marco.fasolo@uniromal.it

Fabio Lanfranchi, Sapienza University of Rome, fabio.lanfranchi@uniroma l.it

To cite this chapter: Carnevali Laura, Fasolo Marco, Lanfranchi Fabio (2020). II Disegno e la Scuola Superiore di Architettura/Drawing and the Advanced School of Architecture. In Arena A., Arena M., Brandolino R.G., Colistra D., Ginex G., Mediati D., Nucifora S., Raffa P. (a cura di). Connettere. Un disegno per annodare e tessere. Atti del $42^{\circ}$ Convegno Internazionale dei Docenti delle Discipline della Rappresentazione/Connecting. Drawing for weaving relationships. Proceedings of the 42th International Conference of Representation Disciplines Teachers. Milano: FrancoAngeli. pp. 238-259. 